Chapter 31

\title{
Risks of Heavy Metals Contamination of Soil-Pant System by Land Application of Sewage Sludge: A Review with Data from Brazil
}

\author{
Alysson Roberto Baizi e Silva and Fábio Camilotti \\ Additional information is available at the end of the chapter \\ http://dx.doi.org/10.5772/58384
}

\section{Introduction}

The discharge of urban sewage directly to rivers and lakes is among the principal causes of surface water contamination. Contaminated water resources threaten the water supply of cities and the ecological equilibrium of aquatic ecosystems. To minimize or avoid these negative impacts, the sewage needs to be treated.

Sewage treatment is increasing to the extent that is necessary to maintain the water quality. However, despite purifying municipal wastewater, making it suitable for discharge in receiving water bodies such as rivers and lakes, the sewage treatment process generates a large volume of sludge that needs to be destined appropriately and quickly to avoid its accumulation and consequently its transformation into environmental liabilities in wastewater treatment plants (WTPs).

The options for disposal of sewage sludge are varied. In general, they include: (i) land application, (ii) industrial reuse, (iii) disposal in landfills, (iv) incineration and (v) discharge to oceans [1]. Land application and disposal in landfills are the most widely adopted disposal methods in various parts of the world [2,3]. The application to land is considered the most attractive option, because the sewage sludge can improve soil conditions for agricultural production, since it is rich in organic matter and plant nutrients $[4,5]$. However, there are undesirable constituents in its composition.

Heavy metals, such as cadmium $(\mathrm{Cd})$, lead $(\mathrm{Pb})$, among others, are the most concern undesirable constituents [5-7], since they may be toxic to microorganisms, plants, animals and humans in not very high concentrations [8-10]. Therefore, soils amended with sewage sludge should be evaluated for heavy metal contamination in order to prevent its excessive entry into the 
food chain, thus reducing the risk of toxicity in living organisms posed by the method of disposal of sludge on land.

The evaluation of heavy metals in soil can be made in several ways. The basic and most common is to quantify the total concentration [11]. The great advantage of this measure is its robustness, that is, it does not easily change with environmental conditions, but it may be altered by the addition of metals from external sources, such as sludge, which allows its use as an indicator of soil contamination by heavy metals. However, the total concentration not satisfactorily represents the amount of metal that would be available for uptake by plants, that is, the fraction of contaminant which could cause phytotoxicity and enter the food chain, affecting animals and humans. Due to its direct relationship with potential toxic effects, the available concentration should be determined in addition to total concentration.

The availability of heavy metals to plants has been characterized using chemical extractants, some of them already employed in routine soil analysis, as Mehlich 1, Mehlich 3 and DTPA. In general, extractants are (i) acid, (ii) chelating agents, (iii) acid-chelating or (iv) saline solutions [11]. The chemical nature of the extracting solution interferes with the ability of extracting metals and, ultimately, the efficiency of the extractant to represent the available fraction. Therefore, the extractants should be systematically tested before being used in monitoring heavy metals in soils amended with sewage sludge.

Fractionation is also interesting technique to evaluate heavy metals in soils. Its principle is to separate the metals in soil fractions in which they have variable solubility [12]. With this procedure, it is possible to determine the contribution of each fraction in the availability of metals to plants $[13,14]$. It also allows selecting the best chemical extractant, based on its relationship with the fractions that most contribute to uptake of metals by plants. Moreover, the redistribution of metals among fractions in response to changes in soil conditions can be studied [15]. Thus, the fractionation can indicate whether the metals added to the soil by the sludge are to be redistributed in fractions in which they are either more or less available, that is, whether they have either greater or lesser potential to cause toxicity problems respectively $[7,16]$.

The study of speciation is another interesting strategy to evaluate heavy metals in soils, since it enables to distinguish different chemical species in the soil solution. Each species has a particular chemical behavior in terms of availability and mobility in soil. Free ions are more relevant to the availability of metals, because they are the preferred forms of plant uptake [11]. In contrast, organo-metal complexes are more related to the mobility of metals and, consequently, to their leaching [17]. Thus, the speciation can indicate if the risk of phytotoxicity and contamination of the food chain is higher or lower than the risk of groundwater contamination, based on the proportion of the chemical species formed in response to application of sewage sludge.

Besides the contamination of soil, it is also necessary to evaluate whether the sewage sludge applied to land can contaminate crops with heavy metals. The assessment of crop contamination must include studies of differential capacity of uptake, translocation, accumulation and allocation of metals in different plant species. In the case of allocation, it is essential to evaluate 
the metals of interest in the harvested parts, especially those that are edible [18]. As a result of these investigations, plants can be separated by their susceptibility to contamination with heavy metals and thus the indication of using less susceptible plants in areas that receive sewage sludge can be made.

In Brazil, the sewage treatment has grown considerably in recent years. In 2001, $25.6 \%$ of the sewage generated were treated [19]. Ten years later, in 2011, this index had risen to $37.5 \%$ [20]. Growth should remain strong, since there is a significant amount of resources to be invested in sanitation in the country [21]. The expansion in sewage treatment causes inevitable increase in the generation of sewage sludge.

The Brazilian production of sewage sludge is estimated at 150-220 thousand tons per year (dry basis) [22] with a perspective to increase. As in other parts of the world, land application has been one of the preferred forms of sludge disposal [1]. As seen above, this option requires a careful evaluation of heavy metals in soils amended. In recent decades, many experiments have been conducted in Brazil to evaluate the effects of sewage sludge on heavy metals in soils and crops. The results of these works can help technicians to manage more safely sludge application to land.

Thus, our objective was to review the scientific literature on the impacts of sewage sludge on heavy metals in soils and plants in conditions of Brazil, attempting to evaluate the risks of contamination of the soil-plant system. We focused on studies involving field experiments because they represent better real situations of management of the sludge.

\section{Heavy metals: An overview}

Heavy metals comprise a class of not very well defined chemical elements. They have been commonly characterized as metals and metalloids (semimetals) with density higher than $5 \mathrm{~g}$ $\mathrm{cm}^{-3}$ associated with problems of environmental contamination and toxicity, although some of them are required in low concentrations for some organisms such as higher plants, animals and humans [23, 24]. However, this definition (attempt) has been criticized for its chemical and toxicological inadequacy and it has had no institutional support of IUPAC (International Union of Pure and Applied Chemistry) [25]. Despite the criticism, there is no more appropriate term to refer collectively to the elements known as heavy metals. Therefore, we use this terminology in this text and support its use in the definition introduced by Hawkes [26], according to which heavy metals comprise a block in the Periodic Table with all metals and metalloids in Groups 3 to 16 that are in periods 4 and greater. As some authors consider selenium (Se) it as a metalloid and therefore heavy metal [10, 27], we also consider it as metalloid in this chapter, even though it is a non-metal. Thus, we expand the definition of Hawkes [26] to include Se as a heavy metal, keeping in mind which this redefinition is simply operating, just to join in the same class specific chemical elements commonly associated to problems of environmental contamination and toxicity.

Heavy metals can be divided according to their need for different organisms. There are those which are doubtless essential and those which are not recognized as essential (Table 1). Copper 
$(\mathrm{Cu})$, iron $(\mathrm{Fe})$, manganese $(\mathrm{Mn})$, molybdenum $(\mathrm{Mo})$ and zinc $(\mathrm{Zn})$ are essential to plants, animals and humans. Cobalt (Co) and Se are essential only to animals and humans, while chromium ( $\mathrm{Cr}$ ) and nickel (Ni) are essential to humans and plants, respectively. In contrast, arsenic (As), $\mathrm{Cd}, \mathrm{Pb}$ and mercury $(\mathrm{Hg})$ are not essential to any of these organisms. However, essential or not essential metals may be toxic. For example, manganese (Mn) is an essential element (i.e., micronutrient) to plants, but its excessive uptake can cause toxicity in crops [28, 29]. On the other hand, $\mathrm{As}, \mathrm{Cd}, \mathrm{Pb}$ and mercury $(\mathrm{Hg})$ are not essential to humans but in excess can also cause toxicity. People exposed to $\mathrm{Pb}$ or $\mathrm{Hg}$ develop neurological disorders, while exposure to $\mathrm{Cd}$ is associated with kidney damage and fragile bones, and various forms of cancer can occur due to the ingestion of food or water contaminated with As [30]. A summary of the toxicity of heavy metals commonly associated with environmental contamination is given in Table 1.

\begin{tabular}{|c|c|c|c|c|}
\hline $\begin{array}{l}\text { Heavy metal } \\
\text { (Symbol) }\end{array}$ & Organismt & Essentiality $\ddagger$ & Toxicity§ & Reference \\
\hline \multirow{3}{*}{ Arsenic (As) } & Plants & No & $\begin{array}{l}\text { Increased oxidative stress and reduced plant } \\
\text { growth. }\end{array}$ & [31-33] \\
\hline & Animals & No & Blindness and reduced weight gain. & [9] \\
\hline & Humans & No & Increased cancer risk. & [30] \\
\hline \multirow{3}{*}{ Cadmium $(\mathrm{Cd})$} & Plants & No & $\begin{array}{l}\text { Increased oxidative stress and reduced plant } \\
\text { growth. }\end{array}$ & {$[34,35]$} \\
\hline & Animals & No & Reduced weight gain. & {$[36]$} \\
\hline & Humans & No & Kidney damage and fragile bones. & {$[30]$} \\
\hline \multirow{3}{*}{ Chromium (Cr) } & Plants & No & $\begin{array}{l}\text { Increased oxidative stress and reduced plant } \\
\text { growth. } \mathrm{Cr}(\mathrm{VI}) \text { is more toxic than } \mathrm{Cr}(\mathrm{III}) \text {. }\end{array}$ & {$[9,37]$} \\
\hline & Animals & No & $?$ & [38] \\
\hline & Humans & Yes & $\begin{array}{l}\text { Allergy and increased cancer risk. } \mathrm{Cr}(\mathrm{VI}) \text { is more toxic } \\
\text { than } \mathrm{Cr}(\mathrm{III}) \text { or } \mathrm{Cr}(\mathrm{V}) \text {. }\end{array}$ & [39-41] \\
\hline \multirow{3}{*}{ Cobalt (Co) } & Plants & No & $\begin{array}{l}\text { Chlorosis in younger leaves (restricted Fe } \\
\text { translocation) and reduced plant growth. }\end{array}$ & {$[42,43]$} \\
\hline & Animals & Yes & Body weight loss and muscular incoordination. & {$[9,44]$} \\
\hline & Humans & Yes & Cardiomyopathy and Increased cancer risk. & {$[45]$} \\
\hline \multirow{3}{*}{ Copper (Cu) } & Plants & Yes & $\begin{array}{l}\text { Intervenial chlorosis in younger leaves, reduced } \\
\text { branching, thickening, darkening of rootlets and } \\
\text { reduced plant growth. }\end{array}$ & {$[9,43,46]$} \\
\hline & Animals & Yes & Gastroenterits, liver damage and death. & {$[9,47]$} \\
\hline & Humans & Yes & $\begin{array}{l}\text { Wilson's disease, hemolysis, hepatic necrosis and } \\
\text { kidney damage. }\end{array}$ & {$[9,48]$} \\
\hline \multirow{2}{*}{ Iron (Fe) } & Plants & Yes & $\begin{array}{l}\text { Leaf bronzing, roots with black coating and reduced } \\
\text { plant growth. Common in flooded rice. }\end{array}$ & {$[9,49]$} \\
\hline & Animals & Yes & $\begin{array}{l}\text { Anorexia, diarrhea, metabolic acidosis, reduced } \\
\text { body growth rate and death. }\end{array}$ & {$[9,44]$} \\
\hline
\end{tabular}




\begin{tabular}{|c|c|c|c|c|}
\hline $\begin{array}{l}\text { Heavy metal } \\
\text { (Symbol) }\end{array}$ & Organismt & Essentiality $\ddagger$ & Toxicity§ & Reference \\
\hline & & & Vomiting, diarrhea, metabolic acidosis and & \\
\hline & Humans & Yes & $\begin{array}{l}\text { increased risk of atherosclerosis and Alzheimer's } \\
\text { disease. }\end{array}$ & {$[9,50]$} \\
\hline \multirow{3}{*}{ Lead $(\mathrm{Pb})$} & Plants & No & $\begin{array}{l}\text { Chlorosis, root system darkening, stunted plant } \\
\text { growth and increased oxidative stress. }\end{array}$ & [51] \\
\hline & Animals & No & $\begin{array}{l}\text { Appetite loss, diarrhea, anemia and body weight } \\
\text { loss. }\end{array}$ & [9] \\
\hline & Humans & No & $\begin{array}{l}\text { Neurological problems (from headache to } \\
\text { psychosis) and kidney damage. }\end{array}$ & {$[9,30]$} \\
\hline \multirow{3}{*}{ Manganese (Mn) } & Plants & Yes & $\begin{array}{l}\text { General chlorosis, necrotic leaf spots and stunted } \\
\text { plant growth. }\end{array}$ & [9] \\
\hline & Animals & Yes & $\begin{array}{l}\text { Anemia, gastrointestinal lesions and growth } \\
\text { retardation. }\end{array}$ & [9] \\
\hline & Humans & Yes & $\begin{array}{l}\text { Psychiatric disturbance and neurodegenerative } \\
\text { disorder, including Parkinson's disease. }\end{array}$ & {$[9,52]$} \\
\hline \multirow{3}{*}{ Mercury (Hg) } & Plants & No & $\begin{array}{l}\text { Hypertrophic root, retarded plant growth and } \\
\text { increased oxidative stress. }\end{array}$ & {$[53,54]$} \\
\hline & Animals & No & $\begin{array}{l}\text { Vomiting, bloody diarrhea and necrosis of the } \\
\text { alimentary mucosa. }\end{array}$ & [9] \\
\hline & Humans & No & $\begin{array}{l}\text { Neurological disturbances, kidney damage and } \\
\text { decreased fertility. }\end{array}$ & [30] \\
\hline \multirow{3}{*}{ Molybdenum (Mo) } & Plants & Yes & $\begin{array}{l}\text { Yellow or orange-yellow chlorosis, seedling injury, } \\
\text { delayed maturity and reduced plant growth. }\end{array}$ & {$[9,55]$} \\
\hline & Animals & Yes & $\begin{array}{l}\text { Diarrhea, anorexia, depigmentation of hair and } \\
\text { wool and neurological disturbance. }\end{array}$ & [9] \\
\hline & Humans & Yes & Possibly acting joints, hyperuricosuria and gout. & {$[9,56]$} \\
\hline \multirow{3}{*}{ Nickel (Ni) } & Plants & Yes & $\begin{array}{l}\text { Increased oxidative stress, retarded germination, } \\
\text { stunted root growth, chlorosis, inhibited plant } \\
\text { growth and reduced yield. }\end{array}$ & {$[9,57]$} \\
\hline & Animals & No & $?$ & [37] \\
\hline & Humans & No & $\begin{array}{l}\text { Skin allergies, lung fibrosis, kidney and } \\
\text { cardiovascular system damage and stimulation of } \\
\text { neoplastic transformation. }\end{array}$ & [58] \\
\hline \multirow{3}{*}{ Selenium (Se) } & Plants & No & $\begin{array}{l}\text { Chlorosis, wilted and dried leaves, reduced plant } \\
\text { growth and plant premature death. }\end{array}$ & [59] \\
\hline & Animals & Yes & $\begin{array}{l}\text { Impaired vision, anemia, loss of hair, ataxia, stiffness } \\
\text { of joints, paralysis, atrophy of heart and death. }\end{array}$ & {$[9,60]$} \\
\hline & Humans & Yes & Hypochromic anemia, damaged nails and hair loss. & {$[9,61]$} \\
\hline Zinc (Zn) & Plants & Yes & $\begin{array}{l}\text { Chlorosis (Fe-deficiency-induced), stunted plant } \\
\text { growth and reduced yield. }\end{array}$ & {$[9,62]$} \\
\hline
\end{tabular}




\begin{tabular}{|c|c|c|c|c|}
\hline $\begin{array}{l}\text { Heavy metal } \\
\text { (Symbol) }\end{array}$ & Organism & Essentiality $\ddagger$ & Toxicity§ & Reference \\
\hline & Animals & Yes & $\begin{array}{l}\text { Diarrhea, anorexia, jaundice, kidney and abomasum } \\
\text { damage, arthritis and weight loss. }\end{array}$ & {$[9,63]$} \\
\hline & Humans & Yes & $\begin{array}{l}\text { Diarrhea, nausea, vomiting, epigastric pain, lethargy, } \\
\text { anemia, neutropenia, impaired immune function } \\
\text { and decreased HDL cholesterol. }\end{array}$ & {$[9,64]$} \\
\hline
\end{tabular}

tIn case of animals, they are livestock animals.

¥Yes: essentiality recognized. No: essentiality unrecognized.

$\S$ Most common manifestations, symptoms and consequences of heavy metal toxic effects.

Table 1. Essentiality and toxicity of heavy metals for different organisms.

The relative importance of heavy metals toxicity was addressed by McLaughlin et al. [10] in terms of food chain contamination. According to these authors, $\mathrm{Cd}$ is the metal with greatest potential to contaminate plants and subsequently to be transferred to animals and humans that eat these contaminated plants or part of them. This statement is based on the fact that (i) $\mathrm{Cd}$ poses animal and human health risks in plant tissue concentrations that are not generally phytotoxic and (ii) Cd concentrations in agricultural soils are increasing in many parts of world due to $\mathrm{Cd}$ inadvertent additions through the use of fertilizers, sewage sludge and soil amendments. Due to the high risk of contaminating the food chain, the risk of $\mathrm{Cd}$ to cause toxicity is considered to be high as well. Despite increased concern with $\mathrm{Cd}$, the toxicity risk of other heavy metals should not be neglected.

The toxicity of heavy metals in living organisms is a phenomenon somewhat complex. Toxic effects of a metal depend on a number of factors that often include (i) rate, (ii) exposure time, (iii) tolerance of the organism and (iv) environmental conditions. In recent years, the effect of the interaction between heavy metals on the expression of toxicity has been considered very intensely. As a result of the interaction, a given metal may increase or decrease the negative effects of other metal in the organism [65].

Despite the complexity, the toxicity of heavy metals in plants and in animals and humans that eat contaminated plants is primarily associated with previous environmental contamination. Soils may be contaminated with such hazardous elements by the use of sewage sludge. High concentrations of metals in the sludge increase the risks of contamination and therefore toxicity. Thus, it is important to know the chemical composition of sewage sludge.

\section{Sewage sludge}

Sewage sludge is generally defined as a semi-solid or liquid organic residue generated during the treatment of domestic sewage. He has also been called biosolids, but this term is more appropriate for the sludge that was conveniently selected and treated to allow its application 
to land (i.e., agricultural recycling) [6, 66]. Although the use of the term biosolids is becoming common, sewage sludge was used in this text because it encompasses sludges with different types and degrees of treatment and is the term adopted by the Brazilian legislation [67].

The chemical composition of sewage sludge is highly variable, particularly in terms of heavy metals. Such variability can be seen in Table 2 for sludge generated at WTPs in Brazil. The coefficients of variation (CVs) of heavy metal concentrations are somewhat high. Cd, Co, $\mathrm{Cr}$ and $\mathrm{Ni}$ concentrations had the highest $\mathrm{CVs}$, above $80 \%$, and $\mathrm{Zn}$ the lowest, $43 \%$. Intermediate variability was observed for $\mathrm{Cu}, \mathrm{Fe}, \mathrm{Mn}, \mathrm{Mo}$ and $\mathrm{Pb}$. It was not possible to calculate $\mathrm{CV}$ for $\mathrm{As}, \mathrm{Hg}$ and Se because of the paucity of data. The high variability is explained primarily by the origin of the sludges, since they were obtained in WTP from different cities, each with particular characteristics of generation and wastewater treatment as well as treatment of generated sludge. However, there was also considerable variation for a same city, which indicates the occurrence of temporal variability (e.g., seasonal, annual etc.) for concentration.

Despite the high variability, the concentrations of heavy metals in sewage sludge for land application may not exceed limits established by environmental institutions. In Table 2 two limits for each metal are shown, one from the Environmental Agency of the State of São Paulo (CETESB) and other from the Brazilian National Environment Council (CONAMA). There is agreement for the limits between the institutions only for the Se. For all elements, CONAMA limits are lower. As CONAMA rule is federal and more restrictive, it must prevail over the rule of CETESB, which is state and less restrictive.

Considering Resolution \# 375/2006 of CONAMA, some sewage sludges presented in Table 2 had heavy metal concentrations above the established limits. Seven, six, four and three sludges were with concentrations of $\mathrm{Zn}, \mathrm{Ni}, \mathrm{Cr}$ and $\mathrm{Pb}$, respectively, higher than the maximum allowable concentrations. Generally, more than one metal was in excess, but not necessarily. Improper sludges were generated in the cities of Barueri, Franca and São Paulo, however, Franca produced sludges less contaminated with heavy metals, which probably reflects its lower level of industrialization in relation to the other two cities.

The concentrations of $\mathrm{Cd}$ and $\mathrm{Cu}$ in sewage sludges were below the limits of CONAMA (Table 2). Similarly, the concentrations of $\mathrm{As}, \mathrm{Hg}$, Mo and Se were also below, but there were few values determined, making this finding unrepresentative. However, the high number of cases in which these elements were below the limit of detection (LOD) of the analytical method suggests low concentrations, probably far from reaching the maximum allowable concentrations. Although they are not legally restrictive, $\mathrm{Co}$, Fe and $\mathrm{Mn}$ were in relatively high concentrations in the sludges analyzed.

The finding that the Cd did not exceed the limit established by CONAMA is the most positive result of this survey of sewage sludge used in experiments conducted in Brazil. This result indicates that the sludge has low potential for soil contamination with this heavy metal. Soil contaminated with $\mathrm{Cd}$ is a constant concern throughout the world, because this metal can easily enter the food chain and impose risks to human health [10]. On the other hand, the sludge seems to be a considerable source of other heavy metals such as $\mathrm{Cr}$ and $\mathrm{Pb}$. Considering that 


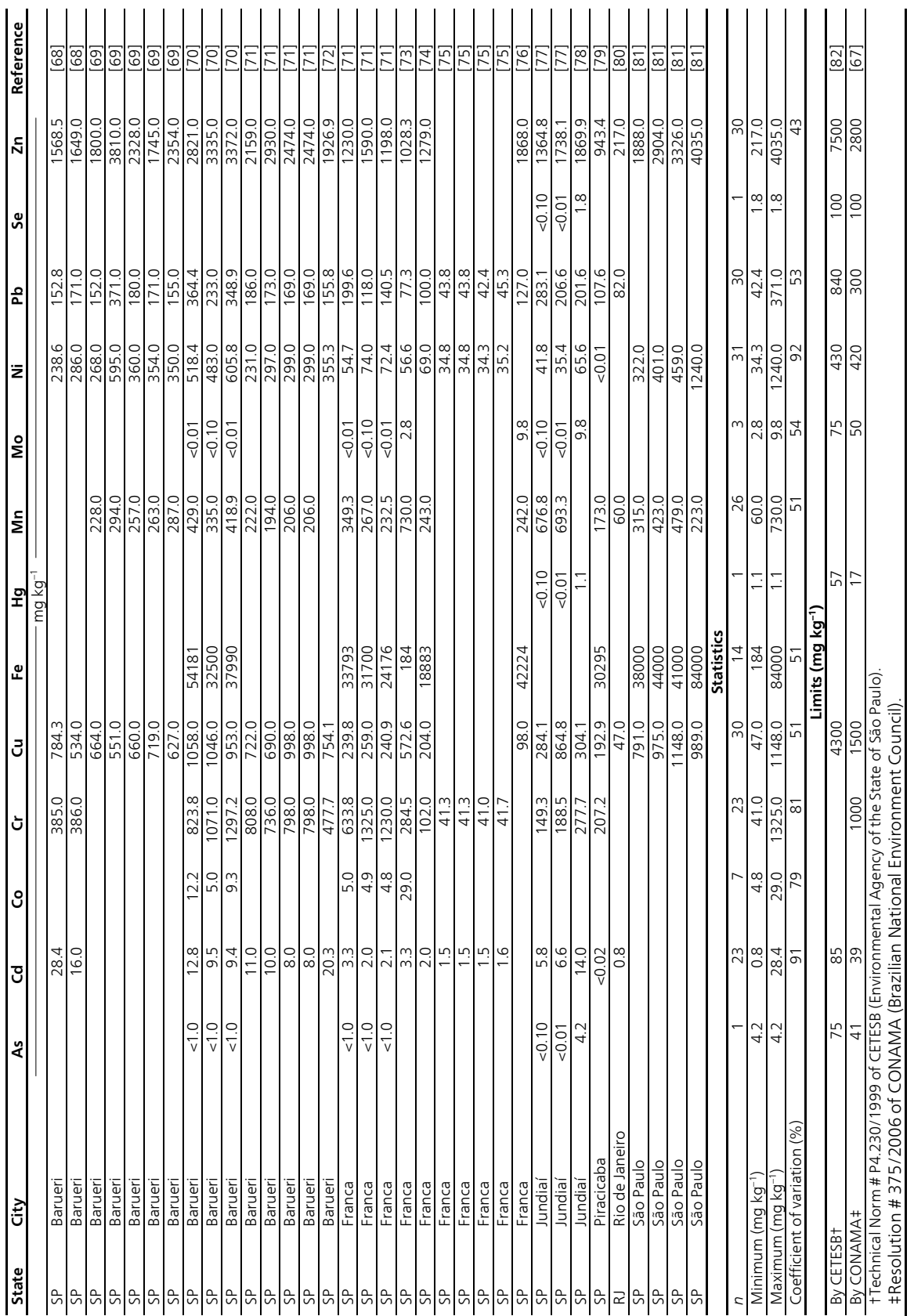

Table 2. Heavy metals in sewage sludge samples used in experiments conducted in Brazil. 
the sludge can introduce these metals in excess, soils amended with sewage sludge should be carefully evaluated for accumulation and availability of $\mathrm{Cu}, \mathrm{Cr}, \mathrm{Mn}, \mathrm{Pb}$ and $\mathrm{Zn}$. Additionally, the $\mathrm{Cd}$ should also be monitored because it is highly dangerous.

\section{Heavy metals in soils amended with sewage sludge}

\subsection{Total concentration}

The determination of the total concentration of heavy metals in soils has been performed with previous extraction of metals from samples using different mixtures of acids. In Brazil, the methods of extraction most widely used are presented in Table 3. Because of the difference in the chemical composition, some of them may produce quite contrasting results. Comparison between the methods $\mathrm{HNO}_{3}-\mathrm{H}_{2} \mathrm{O}_{2}-\mathrm{HCl}$ and $\mathrm{HClO}_{4}-\mathrm{HF}$ shows this contrast. It is observed in Table 4 that concentrations of $\mathrm{Cr}, \mathrm{Pb}$ and $\mathrm{Zn}$ extracted with $\mathrm{HNO}_{3}-\mathrm{H}_{2} \mathrm{O}_{2}-$ $\mathrm{HCl}$ were $72 \%, 31 \%$ and $62 \%$ lower than concentrations of these metals extracted with $\mathrm{HClO}_{4}-\mathrm{HF}$. For $\mathrm{Cd}$, however, the results were not different between the two methods, suggesting that the difference in values between them may depend on the type of metal in question. The contrasting results between these methods are due to extraction differential capacity of the reagent mixtures employed in each of them. The $\mathrm{HNO}_{3}-\mathrm{H}_{2} \mathrm{O}_{2}-\mathrm{HCl}$ mixture does not normally extract metals bound to silicates. On the other hand, hydrofluoric acid contained in the $\mathrm{HClO}_{4}-\mathrm{HF}$ mixture is able to dissolve silicates and extract metals eventually present in this mineral class. Therefore, concentrations of metals extracted with $\mathrm{HNO}_{3}-\mathrm{H}_{2} \mathrm{O}_{2}-\mathrm{HCl}$ tend to be smaller in relation to extraction with $\mathrm{HClO}_{4}-\mathrm{HF}$. Thus, it is necessary to standardize the method of extraction of heavy metals to assess the contamination of soil amended with sewage sludge.

\begin{tabular}{|c|c|c|c|c|}
\hline Extraction method & Common name & External heating & Denomination by USEPAT & Reference \\
\hline $\mathrm{HNO}_{3}-\mathrm{H}_{2} \mathrm{O}_{2}-\mathrm{HCl}$ & & & Method 3050B & [83] \\
\hline $\mathrm{HNO}_{3}-\mathrm{HCl} 1+3$ & Aqua regia & Microwave oven & Method 3051A & [84] \\
\hline $\mathrm{HNO}_{3}-\mathrm{HClO}_{4} 5+1$ & Nitric-perchloric & & & [85] \\
\hline $\mathrm{HClO}_{4}-\mathrm{HF}$ & & & & [86] \\
\hline
\end{tabular}

+United States Environmental Protection Agency. The composition of the extraction methods 3050B and 3051A may vary slightly but it always has $\mathrm{HNO}_{3}$.

Table 3. Methods commonly used in Brazil for extraction of heavy metals from soils.

Brazilian official institutions of environment, as CETESB [82] and CONAMA [67], recommend the use of the methods 3050B and 3051A of United States Environmental Protection Agency (USEPA) $[83,84]$ for extraction of heavy metals in soils amended with sewage sludge. Such methods are not designed to extract fully the metals from the soil, since they normally do not dissolve elements bound to silicates, which are not generally available in the environment, 


\begin{tabular}{lcccc}
\hline & \multicolumn{5}{c}{ Heavy metalt } \\
\cline { 2 - 5 } Extraction method & $\mathrm{Cd}$ & $\mathrm{Cr}$ & $\mathrm{Pb}$ & $\mathrm{Zn}$ \\
\hline & & & & \\
& & & & \\
& $1.93 \mathrm{a}$ & $28.72 \mathrm{~b}$ & $15.72 \mathrm{~b}$ & $64.82 \mathrm{~b}$ \\
\hline $\mathrm{HNO}_{3}-\mathrm{H}_{2} \mathrm{O}_{2}-\mathrm{HCl}$ & $1.99 \mathrm{a}$ & $104.17 \mathrm{a}$ & $23.05 \mathrm{a}$ & $171.97 \mathrm{a}$ \\
\hline $\mathrm{HClO}_{4}-\mathrm{HF}$ & & &
\end{tabular}

†Means within a column followed by the same letter are not significantly different according to Tukey test $(p<0.05)$. Values are means of four sewage sludge rates.

Source: Adapted from Nogueira et al. [71].

Table 4. $\mathrm{Cd}, \mathrm{Cr}$, Pb and $\mathrm{Zn}$ extracted by two different methods from a Brazilian Oxisol amended with sewage sludge.

thus without implications for environmental contamination. They extract only elements which could become environmentally available, consequently harmful to living organisms. As the extraction is not fully, the terms pseudototal concentration and total recoverable concentration have recently been employed to designate the concentrations of metals extracted by these official methods, although the use of the term total concentration is still very common. In recent years, many field experiments with sewage sludge were performed in Brazil, particularly in São Paulo state, therefore there are several data on total concentrations of heavy metals in soil which allow studying the risks of contamination pose by agricultural use of the waste. A summary of these experiments is presented below.

Oliveira and Mattiazzo [68] conducted an experiment with sugarcane to test varying rates of sewage sludge applied to an Oxisol for two consecutive years, in which heavy metals were added in different amounts, including rates above the annual maximum rates allowed in São Paulo state by CETESB. The data in Tables 5 and 6 show that there was at least one rate above the annual rate allowed for $\mathrm{Cd}, \mathrm{Cu}, \mathrm{Ni}, \mathrm{Pb}$ and $\mathrm{Zn}$, but there was no rate higher than the maximum cumulative rate. In soil, the total concentrations of $\mathrm{Cu}$ and $\mathrm{Zn}$ (extraction with $\mathrm{HCl}-$ $\mathrm{HNO}_{3} 3+1$ in microwave) in layer $0-0.20 \mathrm{~m}$ depth increased with increasing sewage sludge rate in two years especially for the higher rates in the second year, indicating a cumulative effect. $\mathrm{Cd}$ and $\mathrm{Pb}$ were below the LOD of the analytical method (Atomic Absorption SpectrometryAAS). Ni was detected only in the second year and at the two highest rates of sludge. The addition of metals above the allowed maximum rates increased total concentrations of $\mathrm{Cu}, \mathrm{Ni}$ and $\mathrm{Zn}$ in the second year above the natural concentrations established for São Paulo state (Tables 3 and 7), suggesting that soils receiving high loads of heavy metals by the application of excessive rates of sewage sludge could be contaminated in a short time.

In addition to the possibility of rapidly contaminating the soil with heavy metals, high rates of sewage sludge cause prolonged effect on contamination. Martins et al. [81] observed linear increases in total concentrations of $\mathrm{Cu}$ and $\mathrm{Zn}$ (extraction with $\mathrm{HNO}_{3}-\mathrm{HClO} 5+1$ ) in a clayey Oxisol in the year of application of sewage sludge single rates which reached maximum of 80 $\mathrm{Mg} \mathrm{ha}^{-1}$, being in this rate added quantities of these metals that exceeded the maximum annual limits established for São Paulo state. Four years later, increases were still linear and the concentrations were similar to the first year, indicating that these elements persist in the soil for a long time. In fact, high persistence is a characteristic of heavy metals added to soils [87]. 
On the other hand, low rates of sewage sludge applied to land do not increase excessively the total concentrations of heavy metals in soils. Oliveira et al. [69] found that the total concentrations of $\mathrm{Cu}, \mathrm{Ni}, \mathrm{Pb}$ and $\mathrm{Zn}$ (extraction with $\mathrm{HNO}_{3}-\mathrm{H}_{2} \mathrm{O}_{2}-\mathrm{HCl}$ ) in $0-0.20 \mathrm{~m}$ layer of an Oxisol cultivated with maize increased after five annual applications of sewage sludge rates up to 10 $\mathrm{Mg} \mathrm{ha}^{-1}$ year $^{-1}$, but the increases did not exceed the limits of these heavy metals allowed in São Paulo state. In the study conducted by Silva et al. [88], the total concentrations of $\mathrm{Cu}, \mathrm{Ni}$ and $\mathrm{Zn}$ (extraction with $\mathrm{HCl}-\mathrm{HNO}_{3} 3+1$ ) in 0-0.20 m layer of a clayey Oxisol cultivated with maize increased in response to rates of sewage sludge from the Barueri and Franca municipalities, but they increased less with Franca sewage sludge, which had lower concentrations of these metals and it was applied at lower rates. Thus, application of low rates of sludge with low concentrations of heavy metals in their composition seems to be a strategy to minimize the excessive accumulation of heavy metals in soils.

However, this strategy may be insufficient for Cd. Nogueira et al. [78] observed that application of $10.8 \mathrm{Mg} \mathrm{ha}^{-1}$ of sewage sludge, rate defined to supply $100 \%$ of $\mathrm{N}$ required by sugarcane, increased total concentrations of $\mathrm{As}, \mathrm{Cd}, \mathrm{Cu}, \mathrm{Ni}, \mathrm{Pb}$ and $\mathrm{Zn}$ (extraction by Method 3051 A - see Table 3) in 0-0.20 m layer of an Ultisol in assessments performed 360 and 720 days after application of the sludge. While the concentrations of $\mathrm{As}, \mathrm{Cu}, \mathrm{Ni}, \mathrm{Pb}$ and $\mathrm{Zn}$ were well below the limits established by CETESB and CONAMA, the concentration of Cd $\left(0.2 \mathrm{mg} \mathrm{kg}^{-1}\right)$ was relatively close to the limit of CETESB ( $<0.5 \mathrm{mg} \mathrm{kg}^{-1}$, Table 7$)$. Although the concentration of $\mathrm{Cd}$ has more than double to reach this limit, the fact that the limit is too low cause concern in relation to any increase in $\mathrm{Cd}$ concentration due to new applications of sewage sludge. In the work of these authors has been reported for the first time in Brazil the effect of sewage sludge on the accumulation of Se in soil. Se concentration increased from 0.068 to $0.092 \mathrm{mg} \mathrm{kg}^{-1}$ with application of $10.8 \mathrm{Mg} \mathrm{ha}^{-1}$ of sludge, but this increase was below the limit of CETESB $(0.25$ $\left.\mathrm{mg} \mathrm{kg}^{-1}\right)$ and far below the limit of CONAMA $\left(5 \mathrm{mg} \mathrm{kg}^{-1}\right)$.

The concentrations of heavy metals presented above refer only to the topsoil ( $0-0.20 \mathrm{~m}$ depth). However, deeper and stratified sampling can give an idea of how these metals are distributed among soil layers. Merlino et al. [73] evaluated the concentrations of $\mathrm{Cd}, \mathrm{Cr}$ and $\mathrm{Pb}$ (extraction with $\mathrm{HNO}_{3}-\mathrm{H}_{2} \mathrm{O}_{2}-\mathrm{HCl}$ ) in the layers $0-0.10,0.10-0.20$ and $0.20-0.40 \mathrm{~m}$ of an Oxisol cultivated with maize after 11 years of annual application of sewage sludge rates up to $20 \mathrm{Mg} \mathrm{ha}^{-1}$. The concentrations of $\mathrm{Cr}$ and $\mathrm{Pb}$ increased only in the $0-0.10 \mathrm{~m}$ layer, suggesting accumulation in the superficial layer. There was no effect on the concentration of $\mathrm{Cd}$. In another study, there was also no effect on total concentrations of $\mathrm{Cd}, \mathrm{Cr}$, $\mathrm{Ni}$ and $\mathrm{Pb}$ (extraction with $\mathrm{HNO}_{3}-\mathrm{H}_{2} \mathrm{O}_{2}-$ $\mathrm{HCl}$ ) in the layers $0-0.10,0.10-0.20,0.20-0.30,0.30-0.40$ e $0.40-0.50 \mathrm{~m}$ depth of a clayey Oxisol after four annual applications up to $15 \mathrm{Mg} \mathrm{ha}^{-1}$ year $^{-1}$ to supply nitrogen (N) for sugarcane [75]. In contrast, Oliveira and Mattiazzo [89] observed significant increases in total concentrations of $\mathrm{Zn}$ (extraction with $\mathrm{HCl}-\mathrm{HNO}_{3} 3+1$ in microwave) until the layer of $0.40-0.60 \mathrm{~m}$ of an Oxisol amended with relatively high rates of sewage sludge $\left(>30 \mathrm{Mg} \mathrm{ha}^{-1}\right.$ year $\left.^{-1}\right)$ for two consecutive years and cultivated with sugarcane, suggesting that $\mathrm{Zn}$ was leached to layers below the incorporation layer of sludge (0-0.20 m depth). For $\mathrm{Cu}$ and $\mathrm{Cr}$, there was no evidence of leaching. It was not possible to assess the mobility of $\mathrm{Cd}, \mathrm{Ni}$ and $\mathrm{Pb}$ in soil, because their concentrations were below the LOD of the analytical method (AAS). 


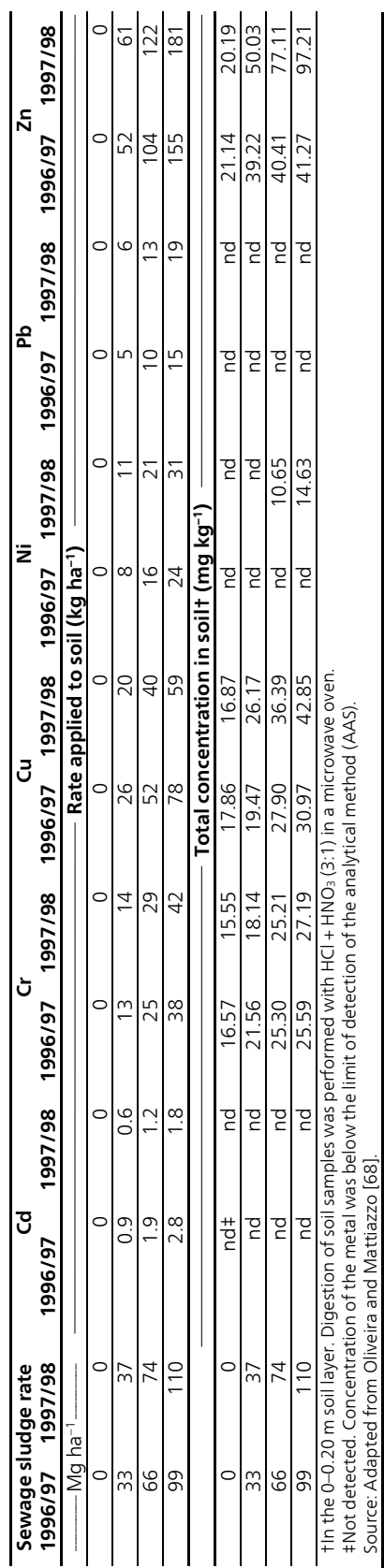

Table 5. Rate and total concentration of heavy metals in a Brazilian Oxisol amended with sewage sludge and cultivated with sugarcane 


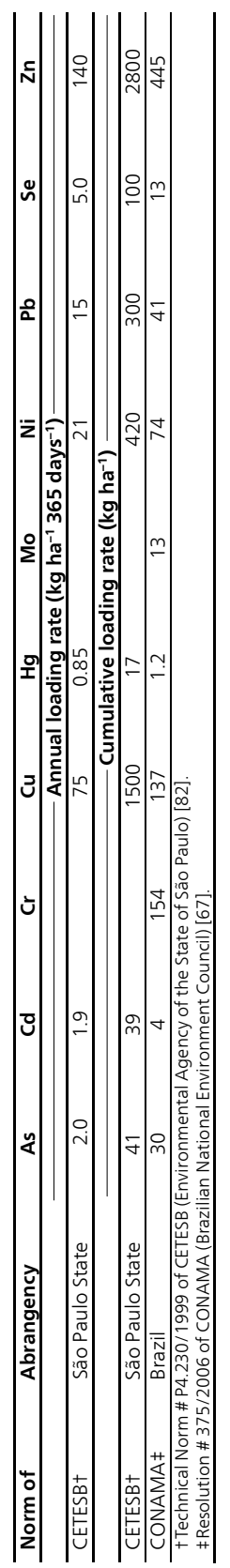

Table 6. Loading rates for heavy metals applied by sewage sludge in São Paulo State and Brazil 


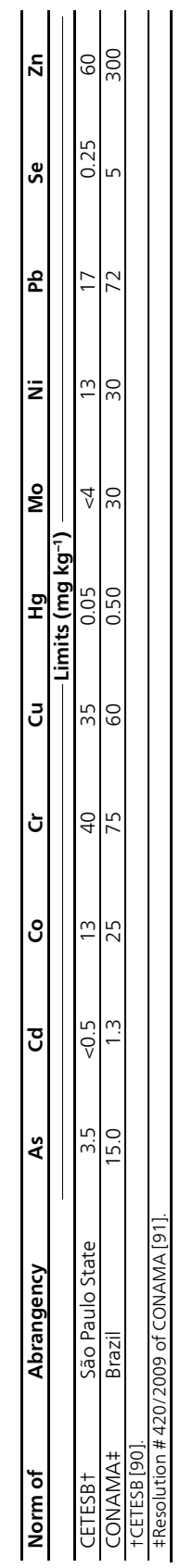

Table 7. Limits for heavy metals in soils from São Paulo State and Brazil 
Besides increasing or not be changed, the concentrations of heavy metals can also decrease in response to the application of sewage sludge, as shown in the work of Macedo et al. [92]. Concentrations of $\mathrm{Cd}, \mathrm{Cr}$ and $\mathrm{Pb}$ (extraction with $\mathrm{HNO}_{3}-\mathrm{H}_{2} \mathrm{O}_{2}-\mathrm{HCl}$ ) were evaluated in the layers $0-0.10,0.10-0.20$ and $0.20-0.40 \mathrm{~m}$ of a clayey Oxisol cultivated with maize after 11 years of application of sludge sewage rates up to $20 \mathrm{Mg} \mathrm{ha}^{-1}$ year-1. In general, the application of sewage sludge reduced the concentrations of heavy metals in the surface layers, with decreasing quite evident for $\mathrm{Cd}$ in layer of $0-0.10 \mathrm{~m}$ depth. This reduction was not expected since metals were added to the soil. Probably, the heavy metals added and part of those natives may have combined with components of sewage sludge forming highly stable compounds resistant to the attack of the extractant used.

\subsection{Availability}

Availability refers to the amount of a chemical (e.g. heavy metal) in the soil that would be available to be absorbed by plants or other biological receptors (e.g. microorganisms). The availability to plants is called phytoavailability, which is a specific term for this class of organisms. In recent years, the availability has also been called bioavailability. Although bioavailability not yet has a clear and accepted definition [93], it has been used to characterize the availability of heavy metals in the environment [94]. However, the uncertainty about the meaning of bioavailability restricts the expansion of its use and thus contributes to the maintenance of the term availability.

The availability of a heavy metal is given by its available concentration. Quantification of the available concentration is performed by extracting the fraction of the metal that is sufficiently soluble to be absorbed by plants. The extraction of this fraction is performed using chemical extractants that try to simulate the potential for uptake of an element of the soil by the roots of plants. There are several extractants which can be used to extract heavy metals from the soil. The extractants used to assess the availability of heavy metals added to Brazilian soils by the application of sewage sludge to land are usually the same ones used in the evaluation of cationic micronutrients, especially Mehlich 1 and DTPA as the most common. Other extractants, as $0.1 \mathrm{~mol} \mathrm{~L}^{-1} \mathrm{HCl}$ and Mehlich 3, have also been used in this assessing. The concentration of a metal in the soil can only be considered available if it is closely and positively correlated with the concentration of the metal in plant tissues. In terms of assessing the contamination, the available concentration can be correlated to the concentration of the metal in raw or processed agricultural product. When there is no correlation or the correlation is poor, it is more appropriate to use the term extractable concentration.

Knowledge of available concentrations is essential for assessing the environmental impact of sewage sludge application to land, since such concentrations represent the amount of heavy metals that could be leached to reach groundwater or could be absorbed by plants and transmitted to the food chain levels until reaching the man. Assessment of the availability of heavy metals in soils amended with sewage sludge was carried out in some field experiments conducted in Brazil. The main results are summarized below.

Oliveira and Mattiazzo [68] found different effects of sewage sludge rates (Table 5) on the availability of some heavy metals evaluated. The sludge was applied for two consecutive years 
to an Oxisol cultivated with sugarcane, and concentrations of available $\mathrm{Cd}, \mathrm{Cr}, \mathrm{Cu}, \mathrm{Ni}, \mathrm{Pb}$ and Zn by extractants $0.1 \mathrm{~mol} \mathrm{~L}^{-1} \mathrm{HCl}$, Mehlich 3 and DTPA were determined in soil samples collected in 0-0.20 m depth one year after each application of the waste. Increase in rates of sewage sludge consistently increased concentrations of $\mathrm{Cu}$ and $\mathrm{Zn}$ extracted with the three extractants in both evaluations. There was increase in concentration of available Ni only at the second assessment and for sewage sludge treatments. The concentrations of $\mathrm{Cd}, \mathrm{Cr}$ and $\mathrm{Pb}$ were below the LOD of the analytical method (AAS). Variations in concentrations of DTPA$\mathrm{Cu}$ and DTPA-Zn between the control (without application of sewage sludge) and the maximum rate of the waste ( $110 \mathrm{Mg} \mathrm{ha}^{-1}$ ) were from 0.70 to $10.70 \mathrm{mg} \mathrm{kg}^{-1}$ and 0.62 to $19.12 \mathrm{mg}$ $\mathrm{kg}^{-1}$, respectively. The higher values of $\mathrm{Cu}$ and $\mathrm{Zn}$ are considered high and very high, respectively, for soils of São Paulo state (Table 8), assuming a similarity between the values expressed in $\mathrm{mg} \mathrm{kg}^{-1}$ and $\mathrm{mg} \mathrm{dm}^{-3}$. However, the authors did not report any negative consequence of these high concentrations to the crop. Positive correlations between the availability of $\mathrm{Cu}$ and $\mathrm{Zn}$ in soil assessed with three extractants and the concentrations of these metals in different plant components (leaf +1 , stalk and juice) were significant when included data from treatments with sewage sludge (three rates), treatment with mineral fertilization and control. However, when included only the sludge treatments, there were few significant correlations, indicating generally low efficiency of extractants to assess the availability of $\mathrm{Cu}$ and $\mathrm{Zn}$ in soil amended with sewage sludge. The exceptions were significant correlations between $0.1 \mathrm{~mol} \mathrm{~L}^{-1} \mathrm{HCl}-\mathrm{Zn}$ and juice- $Z n$ in the two years of evaluation and between $\mathrm{Zn}$ extracted by the three extractants and stalk-Zn and juice-Zn only in the second year.

\begin{tabular}{|c|c|c|c|c|}
\hline \multirow{2}{*}{ Interpretation } & \multicolumn{4}{|c|}{ Limits } \\
\hline & $\mathrm{Cu}$ & $\mathrm{Fe}$ & $M n$ & $\mathrm{Zn}$ \\
\hline & \multicolumn{4}{|c|}{$\mathrm{mg} \mathrm{dm}^{-3}$} \\
\hline Low & $0.0-0.2$ & $0-4$ & $0.0-1.2$ & $0.0-0.5$ \\
\hline Medium & $0.3-0.8$ & $5-12$ & $1.3-5.0$ & $0.6-1.2$ \\
\hline High & $0.9-1.5$ & $13-24$ & $5.1-9.0$ & $1.3-2.3$ \\
\hline Very high & $1.6-15$ & $25-60$ & $10-50$ & 2.4-15 \\
\hline Toxicity & & & & $>130$ \\
\hline
\end{tabular}

Source: Adapted from Abreu et al. [93].

Table 8. Interpretation limits for concentrations of cationic micronutrients extracted by DTPA pH 7.3 in soils from São Paulo State, Brazil

In another study with sugarcane, Nogueira et al. [78] applied sewage sludge rates up to 10.8 $\mathrm{Mg} \mathrm{ha}^{-1}$ to an Ultisol to supply $100 \%$ of $\mathrm{N}$ required by the crop, and after 360 and 720 days they assessed the availability of heavy metals in the layer of 0-0.20 m depth using DTPA. The concentrations of $\mathrm{Cd}, \mathrm{Cu}, \mathrm{Ni}, \mathrm{Pb}$ and $\mathrm{Zn}$ available increased with increasing sludge rates in the two evaluation periods, reaching maximum values of 0.112, 2.64, 0.47, 2.09 and 7.61, respectively. Concentrations of $\mathrm{Cu}$ and $\mathrm{Zn}$ are considered very high (Table 8), while the concentrations of $\mathrm{Cd}, \mathrm{Ni}$ and $\mathrm{Pb}$ are above the normal range for soils of São Paulo state (Table 
9), indicating contamination. Nevertheless, there was no toxicity in the plant. The extractant used was efficient only for $\mathrm{Cd}$ and $\mathrm{Zn}$, since their available concentrations in the soil were highly correlated with the concentrations in leaf with top visible dewlap, stalk and juice. For concentrations of As, $\mathrm{Cr}$ and Se, there was no effect of sewage sludge application. All metals intentionally evaluated in this study were detected, probably by the use of inductively coupled plasma mass spectrometry (ICP-MS), which had LODs very low.

\begin{tabular}{ccccc}
\hline \multirow{2}{*}{ Abragency } & \multicolumn{4}{c}{ Limits } \\
\cline { 2 - 5 } & $\mathbf{C d}$ & $\mathbf{C r}$ & $\mathbf{N i}$ & $\mathbf{P b}$ \\
\hline & & & $\mathrm{mg} \mathrm{dm}^{-3}$ & \\
\hline São Paulo state & 0.020 & 0.030 & 0.180 & 0.85 \\
\hline Other states & 0.019 & 0.007 & 0.147 & 0.76 \\
\hline
\end{tabular}

tValues above the limits are indicative of contamination.

Source: Adapted from Abreu et al. [93].

Table 9. Limits for heavy metals extracted by DTPA pH 7.3 in soils from São Paulo State and other states in Brazilt.

The availability of heavy metals in soils amended with sewage sludge has also been evaluated for maize crop. Martins et al. [81] found that sewage sludge rates up to $80 \mathrm{Mg} \mathrm{ha}^{-1}$ increased the concentrations of extractable $\mathrm{Cu}, \mathrm{Ni}$ and $\mathrm{Zn}$ by DTPA and Mehlich 3 in a clayey Oxisol with or without lime after a maize cultivation. However, the effect of liming on extractability of these metals was different between the two extractants. Liming reduced the concentrations of extractable Ni and $\mathrm{Zn}$ by DTPA, but did not change concentrations of $\mathrm{Cu}$. In the case of Mehlich 3, concentrations of extractable $\mathrm{Cu}$ and $\mathrm{Zn}$ increased with liming, which was unexpected, because it is well known the fact that the increase in soil $\mathrm{pH}$ due to liming generally decreases the availability of cationic micronutrients. Positive correlations between soil $\mathrm{Cu}$ or Zn extracted by DTPA and Mehlich 3 and concentrations of $\mathrm{Cu}$ and $\mathrm{Zn}$ in leaf +4 and shoots of maize were observed, suggesting that extractants were effective in assessing the availability of these micronutrients. In the case of $\mathrm{Ni}$, it has not been possible to establish these relationships because its concentration in plant tissues was below LOD of the analytical method (AAS).

Silva et al. [88] applied sewage sludges from Franca and Barueri municipalities (São Paulo state) in three consecutive crops of maize to a clayey Oxisol. For both sludges, rates were to supply up to eight times the amount of $\mathrm{N}$ required by the crop, reaching maximum values of 30 and $64 \mathrm{Mg} \mathrm{ha}^{-1}$ for sludges of Franca and Barueri, respectively. Soil samples were taken from the layer 0-0.20 m depth after each waste application and before each maize sowing for assessing availability of $\mathrm{Cu}, \mathrm{Mn}, \mathrm{Ni}, \mathrm{Pb}$ and $\mathrm{Zn}$ by DTPA and Mehlich 1 . The concentrations of $\mathrm{Cu}, \mathrm{Ni}$ and $\mathrm{Zn}$ extracted by both extractants increased in response to the application of the two sludges in the three maize crops. For Mn, the extractability varied with sludge, crop and extractant. In extraction with Mehlich 1, the concentration of Mn increased in the three crops for Franca sewage sludge and only in the first crop for Barueri sludge. The concentration of Mn extracted by DTPA increased for both sludges, but only in first and second crops. There were no significant changes in the extractability of $\mathrm{Pb}$ measured by Mehlich 1 for both sludges 
in all crops. In contrast, the concentration of Pb extracted by DTPA increased in all crops for Barueri sludge and in the second crop for Franca sludge. In all cases in which concentrations of extractable metals increased, increases were higher for Barueri sludge, probably because it had the highest concentrations of metals and was applied in higher rates. Regardless of sewage sludge, increases in concentrations of extractable metals by both extractants were lower in the third than in the second crop, suggesting that successive applications of sewage sludge reduced the solubility of such elements. The significance of the correlations between the concentrations of $\mathrm{Cu}, \mathrm{Mn}, \mathrm{Ni}, \mathrm{Pb}$ and $\mathrm{Zn}$ in soil and leaf below the ear and grains varied with sewage sludge and crop for both extractants, indicating that they were not consistently effective in assessing the availability of these metals to maize. The element that had more cases of significance was $\mathrm{Zn}$.

In long term experiments conducted by Oliveira et al. [69], sewage sludge rates up to $10 \mathrm{Mg}$ ha $^{-1}$ year $^{-1}$ were applied to two Oxisols (Typic Haplorthox and Typic Eutrorthox) for five years and in each year the soils were cultivated with maize. The concentrations of $\mathrm{Cu}, \mathrm{Ni}$ and $\mathrm{Zn}$ extractable by Mehlich 1 in layer of 0-0.20 m depth increased in both soils after the fifth year of sludge application. The concentration of extractable $\mathrm{Pb}$ in this layer increased only in Typic Haplorthox. In layer of 0.20-0.40 m depth, there was an increase in extractability of Ni in both soils, whereas concentrations of extractable $\mathrm{Cu}, \mathrm{Pb}$ and $\mathrm{Zn}$ were increased only in Typic Haplorthox. There was no change in concentration of extractable $\mathrm{Mn}$ in any of the layers of both soils. Although the concentrations of extractable $\mathrm{Cu}, \mathrm{Ni}, \mathrm{Pb}$ and $\mathrm{Zn}$ increased with sludge application, these increases were not adequately correlated with the accumulation of these metals in the shoot and grains of maize plant, indicating that the Mehlich 1 was ineffective in assessing the availability of such heavy metals in both soils. Although the extractant has been inefficient to evaluate the availability, increased extractability in layer of $0.20-0.40 \mathrm{~m}$ depth of Typic Haplorthox suggests that $\mathrm{Cu}, \mathrm{Ni}, \mathrm{Pb}$ and $\mathrm{Zn}$ were leached due application of sewage sludge.

The results presented in Galdos et al. [77] also suggest the occurrence of leaching, but not for all metals evaluated. The authors applied sewage sludge to a clayey Oxisol to supply up to double of $\mathrm{N}$ requirement of maize by two successive crops. The maximum rates were $21.6 \mathrm{Mg}$ $\mathrm{ha}^{-1}$ in first crop and $20.5 \mathrm{Mg} \mathrm{ha}^{-1}$ in second crop. The sludge was incorporated into soil layer of $0-0.10 \mathrm{~m}$ depth. The concentrations of extractable $\mathrm{Cu}, \mathrm{Ni}$ and $\mathrm{Zn}$ by DTPA in soil layers of 0-0.05, 0.05-0.10 e 0.10-0.20 m depth were evaluated 267 days after first application and 179 days after second application. The applications of sewage sludge increased the concentrations of $\mathrm{Cu}$ and $\mathrm{Ni}$ in the layers $0-0.05,0.05-0.10 \mathrm{~m}$ only in the second evaluation, but did not change concentrations in $0.10-0.20 \mathrm{~m}$ layer in any of the evaluations, indicating no leaching, probably because the concentrations of these metals in sludge were low $\left(284.1\right.$ and $864.8 \mathrm{mg} \mathrm{kg}^{-1} \mathrm{Cu}$ and 41.8 and $35.5 \mathrm{mg} \mathrm{kg}^{-1} \mathrm{Ni}$ ). In contrast, $\mathrm{Zn}$ concentrations increased in all layers, including the layer of $0.10-0.20 \mathrm{~m}$ in both evaluations, suggesting that $\mathrm{Zn}$ was leached to the layer below the incorporation layer of sewage sludge. The leaching may have occurred because of high concentrations of $\mathrm{Zn}$ in sludge (11,364.8 and 1,738.1 $\left.\mathrm{mg} \mathrm{kg}^{-1}\right)$. Increased mobility of heavy metals in soils amended with sewage sludge is very concerning because the metals leached can reach groundwater, contaminating it. 


\subsection{Chemical fractions}

In Brazil, field studies about fractionation of heavy metals in soils amended with sewage sludge are scarce. Among the few studies that exist, one of Nogueira et al. [94] can be considered comprehensive because they evaluated $\mathrm{Cd}, \mathrm{Pb}$ and $\mathrm{Zn}$ in different soil fractions [exchangeable (Exch), organic matter (OM), amorphous Fe oxide (AFeO), crystalline Fe oxide (CFeO ), and residual (Res)] and in soil organic matter (SOM) chemical fractions [fulvic acid (FA), humic acid (HA) and humin (Hum)] after nine annual applications of sewage sludge rates up to 20 $\mathrm{Mg} \mathrm{ha}^{-1}$ to a clayey Oxisol cultivated with maize. The Cd concentration in the fraction Res was not altered by application of sewage sludge, and concentrations in other fractions were below the LOD of the analytical method (AAS). Similarly, there was no effect of sludge on concentration of $\mathrm{Pb}$ in fractions $\mathrm{AFeO}, \mathrm{CFeO}$ and Res, and the concentrations in other fractions were below the LOD. In contrast, the sludge application increased the concentration of $\mathrm{Zn}$ in all fractions, mainly in $\mathrm{AFeO}$ and $\mathrm{CFeO}$ fractions, indicating that a considerable part of the added $\mathrm{Zn}$ was adsorbed on these oxides. In the fractions of $\mathrm{SOM}, \mathrm{Cd}$ and $\mathrm{Pb}$ concentrations were not changed in response to sewage sludge application. While the concentration of $\mathrm{Zn}$ in Hum fraction was not changed, the concentrations in FA and HA fractions increased by sludge application, indicating that, in SOM, the added $\mathrm{Zn}$ is bound to fractions less stable and thus can become more easily available in the environment.

In another study, the redistribution of $\mathrm{Ni}$ among humic fractions of a medium-textured Oxisol cultivated with maize and amended with sewage sludge rates up to $20 \mathrm{Mg} \mathrm{ha}^{-1}$ year $^{-1}$ for six years was assessed by Melo et al. [95]. The authors observed that the application of sewage sludge increased more the proportion of $\mathrm{Ni}$ in the humin fraction (Figure 1). This means that the sewage sludge redistributed added Ni preferably to more stable fraction of SOM. As the humin fraction is insoluble in acid and alkaline medium, $\mathrm{Ni}$ associated with it can be considered unavailable to plants and not directly subject to leaching, which favors its accumulation in soil layer where sewage sludge is incorporated.

\subsection{Speciation}

In this work, speciation refers to the separation of heavy metals in different chemical forms and possible oxidation states (e.g., chemical species) in the soil solution. Such metals can be separated basically into free ions, complexes and ion pairs $[11,96]$. The participation of each form in the total concentration of a metal in the soil solution can be estimated by using the following general procedures: (i) extraction of soil solution, (ii) determining total concentration of cations, anions and organic compounds in solution and (iii) calculation of the activity of the metals of interest, based on determined concentrations, using specific software for this purpose. Speciation is the basis of the free ion activity model (FIAM) and also other models, which relate the responses of plants to different chemical species of metals present in the soil solution [96].

Plants uptake heavy metals preferably as free ions. Thus, if these ions are increased in the soil solution, so they can be absorbed in excess, and excessive uptake of these metals can cause phytotoxicity and also contamination of the food chain. Indeed, uptake and toxicity of metals in plants generally correlate better with the activity of free ions $[11,96]$. On the other hand, 


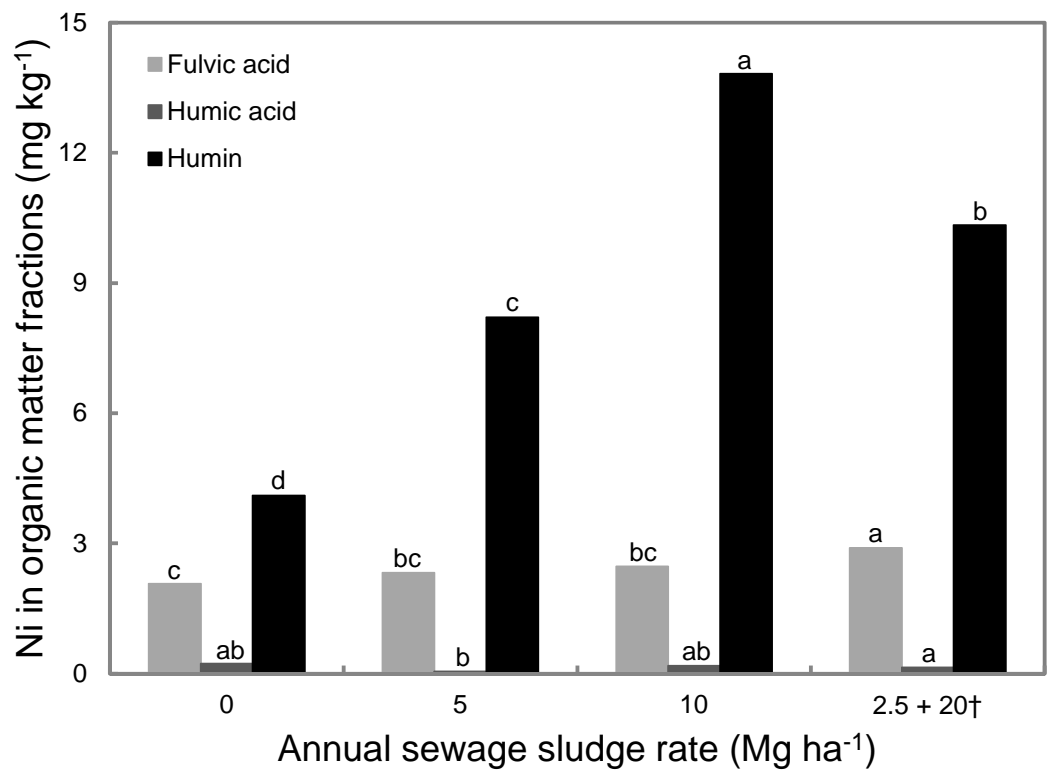

Source: Adapted from Melo et al. [95].

Figure 1. Nickel associated to soil organic matter chemical fractions in medium-textured Oxisol amended with sewage sludge applied annually during six years and cultivated with maize. Means within each fraction followed by the same letter are not significantly different according to Tukey test $(p<0.05) .+2.5 \mathrm{Mg} \mathrm{ha}^{-1}$ in $1 \mathrm{st}$, 2nd, and 3 rd years and 20 $\mathrm{Mg} \mathrm{ha}^{-1}$ in 4th, 5th and 6th years.

other chemical species that are not immediately relevant to the uptake of plants can also cause environmental impact. Heavy metals bound to dissolved organic matter, forming organometal complexes in the soil solution, may have increased their mobility in the soil profile, as demonstrated in experiments with undisturbed soil columns [17], favoring the leaching of these potentially toxic metals, which increases the risk of groundwater contamination

Addition of organic materials to the soil is able to change the availability and mobility of heavy metals in the soil solution, which can minimize some environmental impacts and maximize others. Organic materials added to the soil can decrease the activity of free ions [97] and, consequently, reduce the availability of metals to plants, minimizing the risk of phytotoxicity and contamination of the food chain. In contrast, the addition of organic materials can increase the activity of organo-metal complexes [97] and thus increasing mobility of heavy metals, which become more readily leachable, maximizing the risk of groundwater contamination. Sewage sludge, as an organic material, can also generate these contrasting environmental effects.

As occurs for fractionation, field studies about speciation of heavy metals in soils amended with sewage sludge are also rare in Brazil. The only study found with these characteristics was the Silva's MS thesis [98]. In this work, sewage sludge rates up to $20 \mathrm{Mg} \mathrm{ha}^{-1}$ year $^{-1}$ were applied 
for seven years to a clayey Oxisol cultivated with maize. The author evaluated chemical species of heavy metals in the soil solution from the layer 0-0.20 m depth at 22, 26, 37 and 43 months after the seventh application of sludge. Considering all evaluation times, $\mathrm{Cd}, \mathrm{Cr}, \mathrm{Mo}, \mathrm{Ni}$ and $\mathrm{Pb}$ concentrations in the soil solution were generally below the LOD of the analytical method used (Inductively Coupled Plasma-Optical Emission Spectroscopy-ICP-OES). On the other hand, $\mathrm{Cu}$ and $\mathrm{Zn}$ were consistently detected. The data of speciation for $\mathrm{Cu}$ and $\mathrm{Zn}$ show that application of sewage sludge generally decreased the proportion of these metals as free ions $\left(\mathrm{Cu}^{2+}\right.$ and $\left.\mathrm{Zn}^{2+}\right)$ and increased their proportion as organo-metal complexes [dissolved organic carbon- $\mathrm{Cu}(\mathrm{DOC}-\mathrm{Cu}$ ) and DOC-Zn]. The observed decrease in the proportion of $\mathrm{Cu}$ and $\mathrm{Zn}$ free ions in the soil solution indicates that sewage sludge can restrict the availability and consequently uptake of theses metals by plants, reducing the risk of phytotoxicity and contamination of the food chain. In contrast, increased proportions of COD-Cu and COD-Zn in the soil solution indicate that the sludge can intensify the leaching of $\mathrm{Cu}$ and $\mathrm{Zn}$, increasing the risk of groundwater contamination. These results suggest that the risk of environmental contamination by application of sewage sludge on land should be better assessed considering the intensity these two contrasting effects.

\subsection{Risks of contamination}

Sewage sludge is an organic material containing heavy metals. Therefore, its application to land generates risks of soil contamination by heavy metals. Although it is difficult to quantify this risk, due to the complex interaction among the factors that determine it, it is possible to mention some steps that can minimize it. Knowledge of these measures is relevant, since they allow the adoption of a more appropriate management for the disposal of sewage sludge on land.

As noted above, research about the impact of sewage sludge agricultural use on soil contamination by heavy metals has advanced considerably in recent years in Brazil. Field experiments using the total concentration as an indicator of heavy metal contamination have shown interesting results. Sludge rates above $65 \mathrm{Mg} \mathrm{ha}^{-1}$ year $^{-1}$ can quickly contaminate (approximately two years) the soil by $\mathrm{Cu}, \mathrm{Ni}$ and $\mathrm{Zn}$. Once contaminated with $\mathrm{Cu}$ and $\mathrm{Zn}$, soil may remain in this condition for several years, even without additional application of sewage sludge. Zn may be leached in soils amended with relatively high rates of sludge (>30 $\mathrm{Mg} \mathrm{ha}^{-}$ ${ }^{1}$ year $\left.^{-1}\right)$. In contrast, rates as low as $10 \mathrm{Mg} \mathrm{ha}^{-1}$ year $^{-1}$, applied for five years, have low potential for soil contamination by $\mathrm{Cu}, \mathrm{Ni}, \mathrm{Pb}$ and $\mathrm{Zn}$. Single application of sludge rate of this magnitude is unlikely to contaminate soil for As and may be insufficient to cause contamination by $\mathrm{Cd}$. But as the limits for $\mathrm{Cd}$ in soils are very low (Table 7), any increase in its total concentration is concerning. Therefore, maximum rates for annual increase of $\mathrm{Cd}$ total concentration in soil could be adopted as an optional security criterion to restrict application of sewage sludge on land even though there is no legal restriction to its application.

Studies reviewed in this work also show the usefulness of available concentration to assess soils contaminated by heavy metals. Sewage sludge rates relatively low $\left(\sim 10 \mathrm{Mg} \mathrm{ha}^{-1} \mathrm{year}^{-1}\right)$ can contaminate soil by $\mathrm{Cd}$ and $\mathrm{Zn}$ due to the excessive increase in available concentrations of these metals by DTPA. Similarly, soil contamination by $\mathrm{Cu}$ and $\mathrm{Zn}$, indicated by increase in 
available concentrations by DTPA and Mehlich 3, may occur by applying high sludge rates. Liming reduces the availability of $\mathrm{Zn}$ and hence the potential for contamination of the soil, but only DTPA is able of detecting this reduction. Mehlich 1 extractant, which is widely used in routine soil analysis (soil testing) in Brazil, seems to be inefficient to assess whether a soil is contaminated by heavy metals. Likewise, Mehlich 3 and DTPA are not always efficient. The alternative extractant $0.1 \mathrm{~mol} \mathrm{~L}^{-1} \mathrm{HCl}$ has also shown poor performance. As the factors associated to inefficiency of the extractants are variables (e.g., type of heavy metal, soil class, type of crop, cropping sequence and origin of sewage sludge) and they may act in combination, the available concentration can not yet be considered a consistent and relatively safe indicator for assessing the risk of heavy metals contamination in soils amended with sewage sludge.

Nevertheless, extractable concentrations by DTPA and Mehlich 1 may be useful to monitor the leaching of heavy metals in soils amended with sewage sludge. Relatively low sludge rates ( $10 \mathrm{Mg} \mathrm{ha}^{-1}$ year ${ }^{-1}$ ) applied for a long time (5 years) stimulate the leaching of $\mathrm{Cu}, \mathrm{Ni}$ and $\mathrm{Pb}$, as indicated by increase in extractable concentrations by Mehlich 1 in depth. High sludge rates ( $20 \mathrm{Mg} \mathrm{ha}^{-1}$ year-1 $^{-1}$ ) with high concentration of $\mathrm{Zn}$ in its composition $\left(>1,300 \mathrm{mg} \mathrm{kg}^{-1}\right)$ have the potential to leach $\mathrm{Zn}$ from the superficial layers of the soil in a short time (2 years), as suggested by the increase in extractable concentrations by DTPA in depth. Thus, the extractable concentration, used in the monitoring of leaching, can help in assessing the risk of groundwater contamination by these heavy metals added to the soil by sewage sludge application to land.

The results of fractionation of heavy metals, albeit very limited, have shown opposite trends for $\mathrm{Zn}$ and $\mathrm{Ni}$. $\mathrm{Zn}$ added to the soil by the sludge is preferably bound to $\mathrm{Fe}$ and $\mathrm{Al}$ oxides. In this form, its solubility is limited and thus the risk of being excessively absorbed by plants or leached is reduced. On the other hand, added $\mathrm{Zn}$ which binds to SOM is most often associated with fulvic and humic acids. As these humic substances are poorly stable, its transformation tends to release $\mathrm{Zn}$ retained in soil organic matrix, thereby increasing the risk of contamination. In contrast, added $\mathrm{Ni}$ which binds to SOM is mainly in humin fraction. Since this fraction is very stable, it restricts the solubility of $\mathrm{Ni}$, minimizing the risk of contamination of crops and groundwater.

Speciation of heavy metals in soils amended with sewage sludge is still incipient. We found only one work on this topic, which is a MS thesis. The results of this thesis, however, have shown significant trends. Applications of sewage sludge rates as low as $20 \mathrm{Mg} \mathrm{ha}^{-1} \mathrm{year}^{-1}$ for seven years declined forms of $\mathrm{Cu}$ and $\mathrm{Zn}\left(\mathrm{Cu}^{2+}\right.$ and $\left.\mathrm{Zn}^{2+}\right)$ that are preferentially absorbed by plants, but increased forms of these metals (Cu-DOC and DOC - Zn) that are easily leached. This means that the sewage sludge, when applied in low rates over a long period, decreases the risk of phytotoxicity and contamination of the food chain, but increases the risk of groundwater contamination.

Simultaneous use of different measures to evaluate heavy metals in soils can increase security in the risk assessment of environmental contamination due to the application of sewage sludge to land. From this perspective, total concentration, available concentration, chemical fractions and chemical species of metals should be assessed together to better characterize the dynamics of possible contamination. These different measures represent a gradient of solubility with immediate and potential impact on plant uptake and leaching of heavy metals in soils. Thus, 
the environmental risk posed by the application of sewage sludge could be predicted for short and long term. In addition, these integrated measures could also be useful for the development of mathematical models to predict the availability of heavy metals as free ions using easily measurable input variables (e.g., total metal concentration, $\mathrm{pH}$ and SOM) [96]. Such models would be particularly advantageous in predicting the activity of free ions in response to changes in soil properties by the application of sewage sludge [96]. We did not find studies in Brazil using this integrated approach. The studies summarized in this work enable only superficial considerations, because the data are from independent experiments, and only for $\mathrm{Zn}$, since it was the only metal with results for all measures. Total concentration is shown to be a good measure of soil contamination by Zn, but only at high rates of sewage sludge. Under these conditions, the leaching of metal can be found by the total concentration. For relatively low rates of sludge, however, this measure suggests only low potential for contamination. In both cases, it is not possible to establish a close and reliable relationship between total concentration and toxic effects. Nevertheless, availability and chemical fractions indicate environmental contamination even with application of relatively low rates of sludge. Speciation, in turn, suggests that the leaching of Zn may be more relevant than its excessive uptake by plants, which increases the risk of groundwater contamination to the detriment of phytotoxicity and contamination of the food chain.

\section{Heavy metals in crops grown on soils amended with sewage sludge}

\subsection{Concentration in plants}

Land application of sewage sludge can successively increase heavy metals availability in soil, uptake by plants and accumulation in plant tissues. Thus, concentration in plant tissue can be used as an indicator of heavy metals transfer from soils amended with sludge to plants and of the entry of hazardous elements in the food chain. It can also be used to evaluate the phytotoxicity and contamination of harvested products by heavy metals added to the soil by sewage sludge application, thus presenting important role in determining crop performance and quality of food originated in field. The concentrations of heavy metals in plants vary depending on several factors, including rate of sewage sludge, type of heavy metal, type of plant and analyzed plant part. These factors were studied in field experiments conducted in Brazil, particularly in São Paulo state. Their main results are summarized below.

Galdos et al. [77] evaluated the concentrations of $\mathrm{Cu}, \mathrm{Ni}$ and $\mathrm{Zn}$ in the middle third of the leaf below the ear of maize grown for two years on a clayey Oxisol amended with sewage sludge to supply up to twice the $\mathrm{N}$ requirement of the crop. The maximum rates were $21.6 \mathrm{Mg} \mathrm{ha}^{-1}$ in the first year and $20.5 \mathrm{Mg} \mathrm{ha}^{-1}$ in the second year. $\mathrm{Cu}$ concentration in the leaf was changed only in the first year, increasing with application of the maximum rate of sludge. The waste had no effect on the concentration of $\mathrm{Ni}$, which was measured only in the second year. For $\mathrm{Zn}$, the concentration in the leaf increased progressively with sewage sludge rates in the two years. The concentrations of $\mathrm{Cu}$ and $\mathrm{Zn}$ were within the range of concentrations suitable for the crop 
[99], indicating no phytotoxicity, which is consistent with the absence of adverse effects of the waste on productivity of grains.

Oliveira et al. [69] applied sewage sludge rates up to $10 \mathrm{Mg} \mathrm{ha}^{-1}$ year $^{-1}$ to two Oxisols (Typic Haplorthox and Typic Eutrorthox) for five years and measured the concentrations of $\mathrm{Cu}, \mathrm{Mn}$, $\mathrm{Ni}, \mathrm{Pb}$ and $\mathrm{Zn}$ in shoot and grains of maize in the 5th year. There was no effect of the sludge on concentration of $\mathrm{Cu}$ in any case. The Mn concentration varied only in the shoot, decreasing in Typic Haplorthox and not having clear effect on Typic Eutrorthox. The sludge did not change the concentration of $\mathrm{Ni}$ in shoot and grains, except for concentration in grains in the Typic Eutrorthox which was below the LOD of the analytical method (AAS). The Pb concentration was not changed in the shoot and it was below the LOD in grains. The concentration of $\mathrm{Zn}$ increased in shoot and grains, with the exception of the concentration in the grains in Typic Eutrorthox, which has not changed. Increased concentrations of $\mathrm{Zn}$ were below the tolerance limit in foods as corn $\left(50 \mathrm{mg} \mathrm{kg}^{-1}\right)$ established by Brazilian Health Surveillance Agency [100].

Silva et al. [88] applied sewage sludge from Franca and Barueri municipalities to a clayey Oxisol in three successive annual crops of maize and measured the concentrations of $\mathrm{Cu}, \mathrm{Mn}$, $\mathrm{Ni}, \mathrm{Pb}$ and $\mathrm{Zn}$ in middle third of leaf opposite and below the ear and in its grains. Sludge rates were defined to supply until eight times the amount of $\mathrm{N}$ required by the crop, reaching maximum values of 30 and $64 \mathrm{Mg} \mathrm{ha}^{-1}$ for sludges from Franca and Barueri, respectively. The concentration of $\mathrm{Cu}$ in leaf increased only in the first crop with Barueri sludge application and in third crop with Franca sludge application. Despite the increase, the values are below the toxic level $\left(>50 \mathrm{mg} \mathrm{kg}^{-1}\right)$ for maize leaf presented in Barbosa Filho et al. [99]. The concentration of $\mathrm{Mn}$ in the leaf increased with increasing sludge rates, except for the first crop when was used Franca sewage sludge. Suitable concentrations of Mn in maize leaf can be as high as 214 $\mathrm{mg} \mathrm{kg}^{-1}$ [99]. No concentration exceeded this value suggesting that there was no toxicity of $\mathrm{Mn}$. The concentration of Ni increased only in second crop by Franca sludge application. On the other hand, the $\mathrm{Zn}$ concentration increased with increasing rates of both sludges and in all crops. The only situation in which the concentration of $\mathrm{Zn}$ in leaf was slightly above the appropriate range of concentrations (15-100 $\mathrm{mg} \mathrm{kg}^{-1}$ ) presented in Barbosa Filho et al. [99] was in third crop with application of higher Barueri sludge rate. However, this excess $\mathrm{Zn}$ in leaf must not have been toxic to the plant, since no symptoms of toxicity were reported. In grains, there was much less cases of elevated concentrations of heavy metals when compared with the leaf, suggesting some limitation in the redistribution of these metals to the harvested plant part. Consistent increases were observed for $\mathrm{Mn}$ in second crop with sludge application, $\mathrm{Ni}$ also in second crop, but with Barueri sludge application, and $\mathrm{Zn}$ in the second and third crops with application of the sludges. In the first crop, metals concentrations were below the LOD of the analytical method used (ICP-OES). The concentrations of $\mathrm{Cu}, \mathrm{Ni}, \mathrm{Pb}$ and $\mathrm{Zn}$ in grains were below the maximum limits for cereals in general (30,5.0, 8.0 and $50 \mathrm{mg} \mathrm{kg}^{-1}$, respectively) by Brazilian Food Industry Association [101] and Mn concentrations were below the critical range presented in Kabata-Pendias and Pendias [102] for grains of plants grown in contaminated soils with Mn. 
Oliveira et al. [71] evaluated the concentrations of $\mathrm{Cd}, \mathrm{Cr}, \mathrm{Pb}$ and $\mathrm{Zn}$ in stem, leaves, straw, ear husk, cobs and grains of maize grown on a clayey Oxisol after nine years of annual applications of sewage sludge rates (Table 10). The Cd concentrations were below the LOD of the analytical method (AAS) $\left(0.06 \mathrm{mg} \mathrm{kg}^{-1}\right.$ in grains and $0.2 \mathrm{mg} \mathrm{kg}^{-1}$ in other plant tissues). $\mathrm{Cr}$ concentration increased in stem and leaves in response to sludge application and was below the LOD in ear husk, cob and grains. Pb concentration increased in stem, leaves and ear husk, did not change in cob and was below the LOD in grains. Except for grains, all plant parts had increases in $\mathrm{Zn}$ concentration. These results show that stem and leaves were the most sensible plant tissues for expressing the effect of sewage sludge rates on $\mathrm{Cr}, \mathrm{Pb}$ and $\mathrm{Zn}$ concentrations in maize.

In other long term experiment, $\mathrm{Cd}, \mathrm{Cr}$ and $\mathrm{Pb}$ concentrations were evaluated in leaf apposite and below the ear, whole plant and grains of maize after 11 annual applications of sewage sludge rates up to $20 \mathrm{Mg} \mathrm{ha}^{-1}$ to an Oxisol [73]. There was no effect of sludge on $\mathrm{Cd}$ and $\mathrm{Pb}$ concentrations in leaf. For $\mathrm{Cr}$ in this plant part, its concentrations were below the LOD $(<0.19$ $\mathrm{mg} \mathrm{kg}^{-1}$ ) of the analytical method (AAS). Similarly, concentrations of these heavy metals were below the LOD in grains (0.03, 0.15 and $0.19 \mathrm{mg} \mathrm{kg}^{-1}$ for $\mathrm{Cd}, \mathrm{Cr}$ and $\mathrm{Zn}$, respectively). When considered the whole plant, $\mathrm{Cd}, \mathrm{Cr}$ and $\mathrm{Pb}$ concentrations were not significantly changed by sewage sludge applications.

There are also results for sugarcane. Camilotti et al. evaluated the concentrations of $\mathrm{Cd}, \mathrm{Cr}, \mathrm{Ni}$ and $\mathrm{Pb}$ in stem and leaves of sugarcane cultivated in a clayey Oxisol after three [103] and four [75] annual applications of sewage sludge rates, which reached a maximum of $15 \mathrm{Mg} \mathrm{ha}^{-1}$, with the goal of supplying $100 \%$ and $200 \%$ of $\mathrm{N}$ required by the crop. There was no effect of three applications of sewage sludge in concentrations of $\mathrm{Cr}$ in stalk and leaves, $\mathrm{Ni}$ in leaves and $\mathrm{Pb}$ in stalk and leaves, as well as Cd concentrations in all plant parts analyzed. $\mathrm{Cr}$ in leaves and $\mathrm{Ni}$ in stalk were below the LOD of the analytical method used (AAS). Similarly, the fourth sludge application did not affect the concentrations of $\mathrm{Pb}$ in leaves, but all other cases the concentrations of evaluated heavy metals were below the LOD.

In an experiment conducted on Ultisol, Nogueira et al. [78] applied sewage sludge rates up to $10.8 \mathrm{Mg} \mathrm{ha}^{-1}$ at sugarcane planting for supplying $\mathrm{N}$ required by the crop and evaluated As, $\mathrm{Cd}, \mathrm{Cr}, \mathrm{Cu}, \mathrm{Ni}, \mathrm{Pb}$, Se and $\mathrm{Zn}$ concentrations in leaf (with top visible dewlap), stalk and juice at the harvest time of plant cane (first year) and ratoon cane (second year). In these two evaluations, As concentration increased in leaf and was not affected in stalk and juice by sludge application. Cd concentration increased in leaf, stalk and juice in both crops. On the other hand, $\mathrm{Pb}$ concentration decreased in stalk and juice of plant cane and was not affected in other situations. $\mathrm{Cu}$ concentration decreased in stalk of plant cane and leaf of ratoon cane and was not affected in other cases. Ni concentration also was not generally affected, but it increased in stalk of plant cane and decreased in stalk of ratoon cane. For $\mathrm{Pb}$ concentration, there was no effect of sludge rates. Se concentration was affected only in leaf of plant cane, increasing with sludge application. Zn concentration increased in all situations. There were no cases of concentration below the LOD probably because the authors used ICP-MS. 


\begin{tabular}{|c|c|c|c|c|}
\hline \multicolumn{2}{|c|}{ Sewage sludge rate } & \multicolumn{3}{|c|}{ Heavy metal in plant tissue } \\
\hline Annual & Cumulative & $\mathrm{Cr}$ & $\mathrm{Pb}$ & $\mathrm{Zn}$ \\
\hline \multicolumn{2}{|c|}{$\mathrm{Mg} \mathrm{ha}^{-1}$} & \multicolumn{3}{|c|}{$\longrightarrow \mathrm{mg} \mathrm{kg}^{-1} \longrightarrow$} \\
\hline & & & Stem & \\
\hline 0 & 0 & $0.13 \mathrm{ct}$ & $0.68 b$ & $15.76 \mathrm{c}$ \\
\hline 5 & 45 & $0.33 b$ & $0.61 \mathrm{~b}$ & $19.11 \mathrm{C}$ \\
\hline 10 & 90 & $0.45 a$ & $0.83 a$ & $26.62 b$ \\
\hline \multirow[t]{2}{*}{$2.5+20 \ddagger$} & 127.5 & $0.19 c$ & $0.47 c$ & $44.35 \mathrm{a}$ \\
\hline & & & Leaves & \\
\hline 0 & 0 & $0.74 b$ & $1.10 \mathrm{c}$ & $29.35 b$ \\
\hline 5 & 45 & $1.20 \mathrm{a}$ & $1.43 b$ & $28.54 \mathrm{~b}$ \\
\hline 10 & 90 & $1.48 \mathrm{a}$ & $1.72 \mathrm{a}$ & $39.34 a b$ \\
\hline \multirow[t]{2}{*}{$2.5+20 \neq$} & 127.5 & $0.67 b$ & $1.64 a b$ & $50.77 a$ \\
\hline & & & Ear husk & \\
\hline 0 & 0 & $<0.3$ & $4.28 \mathrm{ab}$ & $13.03 \mathrm{~b}$ \\
\hline 5 & 45 & $<0.3$ & $3.95 b$ & $12.91 \mathrm{~b}$ \\
\hline 10 & 90 & $<0.3$ & $4.86 \mathrm{a}$ & $17.71 \mathrm{ab}$ \\
\hline \multirow[t]{2}{*}{$2.5+20 \ddagger$} & 127.5 & $<0.3$ & $4.70 a b$ & $20.52 \mathrm{a}$ \\
\hline & & & Cob & \\
\hline 0 & 0 & $<0.3$ & $0.88 a$ & $13.49 b$ \\
\hline 5 & 45 & $<0.3$ & 0.98 a & $15.93 b$ \\
\hline 10 & 90 & $<0.3$ & $1.04 \mathrm{a}$ & $27.47 \mathrm{a}$ \\
\hline \multirow[t]{2}{*}{$2.5+20 \neq$} & 127.5 & $<0.3$ & 0.98 a & $32.35 \mathrm{a}$ \\
\hline & & & Grains & \\
\hline 0 & 0 & $<0.09$ & $<0.4$ & $32.36 a$ \\
\hline 5 & 45 & $<0.09$ & $<0.4$ & $29.32 \mathrm{a}$ \\
\hline 10 & 90 & $<0.09$ & $<0.4$ & $35.77 a$ \\
\hline $2.5+20 \neq$ & 127.5 & $<0.09$ & $<0.4$ & $36.70 \mathrm{a}$ \\
\hline
\end{tabular}

†Means within a column in each plant tissue followed by the same letter are not significantly different according to Tukey test $(p<0.05)$.

$\ddagger 2.5 \mathrm{Mg} \mathrm{ha}^{-1}$ in $1 \mathrm{st}, 2 \mathrm{nd}$, and $3 \mathrm{rd}$ years and $20 \mathrm{Mg} \mathrm{ha}^{-1}$ in 4 th, 5th, 6th, 7th, 8th and 9th years.

Source: Nogueira et al. [71].

Table 10. $\mathrm{Cr}, \mathrm{Pb}$ and $\mathrm{Zn}$ concentrations in stem, leaves, ear husk, cob and grains of maize after nine annual applications of sewage sludge to a clayey Oxisol from São Paulo State, Brazil. 


\subsection{Risks of contamination}

The results reviewed above have shown contrasting effects of sewage sludge on the concentrations of heavy metals in maize and sugarcane. Sludge effects on $\mathrm{Cu}, \mathrm{Pb}$ and $\mathrm{Ni}$ concentrations ranged greatly. On the other hand, its effects were more consistent for Zn. Sludge application generally increased $\mathrm{Zn}$ concentrations in plants, but not in phytotoxic levels. Increases occurred even in edible parts of crops, such as grains of corn, but concentrations did not exceed the limit established by Brazilian legislation. For sugarcane, in addition to $\mathrm{Zn}$ accumulation, $\mathrm{Cd}$ concentrations may also increase with sludge application. However, even increasing, $\mathrm{Cd}$ concentrations remained very low.

These findings support the view that the sewage sludge applied to land has low potential to contaminate maize and sugarcane with heavy metals. However, this does not mean that risks of contamination of other crops are also low. Vegetable crops, for example, can easily be contaminated by heavy metals since they have contact with sewage sludge applied to soil or bed. Because of this high risk of contamination, Brazilian law prohibits the agricultural use of sewage sludge for production of vegetable crops and also other crops [67].

\section{Summary and conclusions}

The expected increase in the generation of sewage sludge in Brazil should intensify its disposal on land. Although the sludge is rich in organic matter and plant nutrients, it has heavy metals in its composition. Due to the presence of potentially toxic metals, application of sludge to land requires a risk assessment of soil-plant system contamination. Knowledge of the sludge composition in terms of heavy metals is the first step in assessing risks of contamination.

We have shown in this work that concentrations of heavy metals in the sludge generated in Brazilian WTPs can vary widely depending on the metal. Cd concentration is extremely variable, while $\mathrm{Zn}$ concentration varies relatively little. High variability of $\mathrm{Cd}$ concentration may hamper the planning sludge application by the need for additional adjustment in order to avoid excessive application of $\mathrm{Cd}$ in soil. Zn concentrations found in the sludges analyzed were very high. Thus, the risk of contamination by $\mathrm{Zn}$ can be considered high as well.

Soil contamination by $\mathrm{Cu}, \mathrm{Ni}$ and $\mathrm{Zn}$, as determined by the total concentration, can be rapid, since high rates of sludge are applied to land. In contrast, low rates of sludge have shown low potential to contaminate soil with $\mathrm{Cu}, \mathrm{Ni}, \mathrm{Pb}$ and $\mathrm{Zn}$. However, available concentrations can indicate contamination by $\mathrm{Cu}$ and $\mathrm{Zn}$ even with application of low rates of sludge. Furthermore, they can detect changes in the solubility of metals due to liming.

Nevertheless, the available concentrations depend on the efficiency of the extractant. DTPA, $0.1 \mathrm{~mol} \mathrm{~L}^{-1} \mathrm{HCl}$, Mehlich 1 and Mehlich 3 have not been as efficient as needed. DTPA has shown best performance among these extractants. DTPA and Mehlich 1 extractants can also be used to monitor the leaching of heavy metals such as $\mathrm{Cu}, \mathrm{Ni}, \mathrm{Pb}$ and $\mathrm{Zn}$ in soils amended with sewage sludge, whose importance is to assess the soil contamination at depth and the potential for contamination of groundwater. The fractionation and speciation data have confirmed that 
Zn has a potential to be leached in soil amended with sludge, which increases the risk of groundwater contamination. Regard to contamination of the plant, the results have shown that the application of sewage sludge has low potential to contaminate maize and sugarcane with $\mathrm{Cu}, \mathrm{Ni}, \mathrm{Pb}$ and $\mathrm{Zn}$.

Despite the apparent low risk of contamination of the soil-plant system by heavy metals due to the application of sewage sludge to land, this review has shown that (i) the results from the field experiments are limited to a restricted number of potentially toxic metals, (ii) the chemical extractantsaregenerally inefficient to estimate the available concentrations for these metals in a range of situations and (iii) the studies on fractionation and speciation of these hazardous elements in soils are still incipient. Furthermore, studies have not used an integrated approach involving total concentration, available concentration, chemical fractions and chemical species of heavy metals to assess more reliably the risk of phytotoxicity and contamination of the food chain and groundwater. Thus, this scenario suggests that the application of sewage sludge to land should be as restrictive as possible in Brazil.

\section{Author details}

Alysson Roberto Baizi e Silva ${ }^{1^{*}}$ and Fábio Camilotti ${ }^{1}$

*Address all correspondence to: alysson.silva@embrapa.br

1 Embrapa Eastern Amazon, Belém, PA, Brazil

2 Jaboticabal College of Technology, Jaboticabal, SP, Brazil

\section{References}

[1] Tsutiya MT. Alternativas de disposição final de biossólidos. In: Tsutiya MT, Comparini JB, Alem Sobrinho P, Hespanhol I, Carvalho PCT, Melfi AJ, Melo WJ, Marques MO. (ed.) Biossólidos na agricultura. São Paulo: SABESP; 2001. p133-180.

[2] National Research Council. Biosolids applied to land: advancing standards and practices. Washington: The National Academies Press; 2002.

[3] Kelessidis A, Stasinakis AS. Comparative study of the methods for treatment and final disposal of sewage sludge in European countries. Waste Management, 2012;32(6) 1186-1195.

[4] Wang M-J. Land application of sewage sludge in China. The Science of the Total Environment, 1997;197(1-3) 149-160. 
[5] Bettiol W, Camargo OA. A disposição de lodo de esgoto em solo agrícola. In: Bettiol W, Camargo OA. (ed.) Lodo de esgoto: impactos ambientais na agricultura. Jaguariúna: Embrapa Meio Ambiente; 2006. p25-43.

[6] Tsutiya MT. Características de biossólidos gerados em estações de tratamento de esgotos. In: Tsutiya MT, Comparini JB, Alem Sobrinho P, Hespanhol I, Carvalho PCT, Melfi AJ, Melo WJ, Marques MO. (ed.) Biossólidos na agricultura. São Paulo: SABESP; 2001. p89-131.

[7] Rossi G, Pennelli B, Socciarelli S, Figliolia A. Effects of medium-term amendment with sewage sludges on heavy metal distribution in soil. Developments in Soil Science, 2002;28A 99-107.

[8] McGrath SP, Chaudri AM, Giller KE. Long-term effects of metals in sewage sludge on soils, microorganisms and plants. Journal of Industrial Microbiology, 1995;14(2) 94-104.

[9] Gupta UC, Gupta SC. Trace element toxicity relationships to crop production and livestock and human health: implications for management. Communications in Soil Science and Plant Analysis, 1998;29(11-14) 1491-1522.

[10] McLaughlin MJ, Parker DR, Clarke JM. Metals and micronutrients - food safety issues. Field Crops Research, 1999;60(1-2) 143-163.

[11] Mattiazzo ME, Berton RS, Cruz MCP. Disponibilidade e avaliação de metais pesados potencialmente tóxicos. In: Ferreira ME, Cruz MCP, Raij B van, Abreu CA. (ed.) Micronutrientes e elementos tóxicos na agricultura. Jaboticabal: CNPq/FAPESP/POTAFOS; 2001. p213-234.

[12] Shuman LM. Fractionation method for soil microelements. Soil Science, 1985;140(1) $11-22$.

[13] Shuman LM. Effect of liming on the distribution of manganese, copper, iron, and zinc among soil fractions. Soil Science Society of America Journal, 1986;50(5) 1236-1240.

[14] Sims JT. Soil pH effects on the distribution and availability of manganese, copper, and zinc among soil fractions. Soil Science Society of America Journal, 1986;50(2) 367-373.

[15] Shuman LM. Zinc, manganese, and copper in soil fractions. Soil Science, 1979;127(1) 10-17.

[16] Sánchez-Martín MJ, García-Delgado M, Lorenzo LF, Rodríguez-Cruz MS, Arienzo M. Heavy metals in sewage sludge amended soils determined by sequential extractions as a function of incubation time of soils. Geoderma, 2007;142(3-4) 262-273. 
[17] Camobreco VJ, Richards BK, Steenhuis TS, Peverly JH, McBride MB. Movement of heavy metals through undisturbed and homogenized soil columns. Soil Science, 1996;161(11) 740-750.

[18] Chumbley CG, Unwin RJ. Cadmium and lead content of vegetable crops grown on land with a history of sewage sludge application. Environmental Pollution Series B, Chemical and Physical, 1982;4(3) 231-237.

[19] Sistema Nacional de Informações sobre Saneamento. Diagnósticos dos serviços de água e esgotos - 2001. Brasília: SEDU-PR/IPEA; 2002.

[20] Sistema Nacional de Informações sobre Saneamento. Diagnósticos dos serviços de água e esgotos - 2011. Brasília: MCIDADES.SNSA; 2013.

[21] Leoneti AB, Prado EL, Oliveira SVWB. Saneamento básico no Brasil: considerações sobre investimento e sustentabilidade para o século XXI. Revista de Administração Pública, 2011;45(2) 331-348.

[22] Pedroza MM, Vieira GEG, Sousa JF, Pickler AC, Leal ERM, Milhomen CC. Produção e tratamento de lodo de esgoto - uma revisão. Revista Liberato, 2010;11(16) 89-188.

[23] Adriano, DC. Trace elements in terrestrial environments: biogeochemistry, bioavailability, and risks of metals. 2nd ed. New York: Springer-Verlag; 2001.

[24] Alloway BJ. Introduction. In: Alloway BJ. (ed.) Heavy metals in soils: trace metals and metalloids in soils and their bioavailability. 3rd ed. Dordrecht: Springer; 2013. p3-10.

[25] ] Duffus JH. "Heavy metals" - A meaningless term? Pure and Applied Chemistry, 2002;74(5) 793-907.

[26] Hawkes SJ. What is a "heavy metal"? Journal of Chemical Education, 1997;74(11) 1374.

[27] Christophersen OA, Lyons G, Haug A, Steinnes E. Selenium. In: Alloway BJ. (ed.) Heavy metals in soils: trace metals and metalloids in soils and their bioavailability. 3rd ed. Dordrecht: Springer; 2013. p429-464.

[28] Foy CD, Chaney R, White C. The physiology of metal toxicity in plants. Annual Review of Plant Physiology, 1978;29 511-566.

[29] Fageria NK, Baligar VC, Clark RB. Micronutrients in crop production. Advances in Agronomy, 2002;77 185-268.

[30] Järup L. Hazards of heavy metal contamination. British Medical Bulletin, 2003;68(1) 167-182.

[31] Requejo R, Tena M. Proteome analysis roots reveals that oxidative stress is a main contributing factor to plant arsenic toxicity. Phytochemistry, 2005;66(13) 1519-1528. 
[32] Geng C-N, Zhu Y-G, Tong Y-P, Smith SE, Smith FA. Arsenate (As) uptake by and distribution in two cultivars of winter wheat (Triticum aestivum L.). Chemosphere, 2006;62(4) 608-615.

[33] Castillo-Michel H, Parsons JG, Peralta-Videa JR, Martínez-Martínez A, Dokken KM, Gardea-Torresdey, JL. Use of X-ray absorption spectroscopy and biochemical techniques to characterize arsenic uptake and reduction in pea (Pisum sativum) plants. Plant Physiology and Biochemistry, 2007;45(6,7) 457-463.

[34] Prasad MNV. Cadmium toxicity and tolerance in vascular plants. Environmental and Experimental Botany, 1995;35(4) 525-545.

[35] Rodríguez-Serrano M, Romero-Puertas MC, Pazmiño DM, Testillano OS, Risueño MC, del Río LA, Sandalio LM. Cellular response of pea plants to cadmium toxicity: cross talk between reactive oxygen species, nitric oxide, and calcium. Plant Physiology, 2009;150(1) 229-243.

[36] Cousins RJ, Barber AK, Trout JR. Cadmium toxicity in growing swine. Journal of $\mathrm{Nu}^{-}$ trition, 1973;103(7) 964-972.

[37] Shanker AK, Cervantes C, Loza-Tavera, H, Avudainayagam S. Chromium toxicity in plants. Environmental International, 2005;31(5) 739-753.

[38] Sutle NF. The mineral nutrition of livestock. 4th ed. Oxfordshire: CABI; 2010

[39] Anderson RA. Chromium as an essential nutrient for humans. Regulatory Toxicology and Pharmacology, 1997;26(1) S35-S41.

[40] Gad SC. Acute and chronic systemic chromium toxicity. The Science of the Total Environment, 1989;86(1-2) 149-157.

[41] Dayan AD, Paine AJ. Mechanisms of chromium toxicity, carcinogenicity and allergenicity: review of the literature from 1985 to 2000. Human \& Experimental Toxicology, 2001;20(9) 439-451.

[42] Liu J, Reid RJ, Smith FA. The mechanism of cobalt toxicity in mung beans. Physiologia Plantarum, 2000;110(1) 104-110.

[43] Chatterjee J. Chatterjee C. Phytotoxicity of cobalt, chromium and copper in cauliflower. Enviromental Pollution, 2000;109(1) 69-74.

[44] Ammerman CB, Goodrich RD. Advances in mineral nutrition in ruminants. Journal of Animal Science, 1983;57(Supplement 2) 519-533.

[45] Simonsen LO, Harbak H, Bennekou P. Cobalt metabolism and toxicology - a brief update. The Science of the Total Environment, 2012;432 210-2015.

[46] Yruela I. Copper in plants. Brazilian Journal of Plant Physiology, 2005;17(1) 145-156.

[47] Perrin DJ, Schiefer HB, Blakley BR. Chronic copper toxicity in a dairy herd. The Canadian Veterinary Journal, 1990;31(9) 629-632. 
[48] Uauy R, Olivares M, Gonzalez M. Essentiality of copper in humans. The American Journal of Clinical Nutrition, 1998;67(5) 952S-959S.

[49] Fageria NK, Santos AB, Barbosa Filho MB, Guimarães CM. Iron toxicity in lowland rice. Journal of Plant Nutrition, 2008;31(9) 1676-1697.

[50] Brewer GJ. Risks of copper and iron toxicity during aging in humans. Chemical Research in Toxicology, 2010;23(2) 319-326.

[51] Sharma P, Dubey RS. Lead toxicity in plants. Brazilian Journal of Plant Physiology, 2005; 17(1) 35-52.

[52] Crossgrove J, Zheng W. Manganese toxicity upon overexposure. NMR in Biomedicine, 2005;17(8) 544-553.

[53] Patra M, Sharma A. Mercury toxicity in plants. The Botanical Review, 2000;66(3) 379-422.

[54] Cargnelutti D, Tabaldi LA, Spanevello RM, Jucoski GO, Battisti V, Redin M, Linares CEB, Dressler VL, Flores EMM, Nicoloso FT, Morsch VM, Schetinger MRC. Mercury toxicity induces oxidative stress in growing cucumber seedlings. Chemosphere, 2006;65(6) 999-1006.

[55] McGrath SP, Micó C, Zhao FJ, Stroud JL, Zhang H, Fozard S. Predicting molybdenum toxicity to higher plants: estimation of toxicity threshold values. Environmental Pollution, 2010;158(10) 3085-3094.

[56] Vyskočil A, Viau C. Assesment of molybdenum toxicity in humans. Journal of Applied Toxicology, 1999;19(3) 185-192.

[57] Sreekanth TVM, Nagajyothi PC, Lee KD, Prasad TNVKV. Occurrence, physiological responses and toxicity of nickel in plants. International Journal of Environmental Science and Technology, 2013;10(5) 1129-1140.

[58] Denkhaus E, Salnikow K. Nickel essentiality, toxicity, and carcinogenicity. Critical Review in Oncology/Hematology, 2002;42(1) 35-56.

[59] Terry N, Zayed AM, Souza MP, Tarum AS. Selenium in higher plants. Annual Review of Plant Physiology and Plant Molecular Biology, 2000;51 401-432.

[60] Koller LD, Exon JH. The two faces of selenium - deficiency and toxicity - are similar in animals and man. Canadian Journal of Veterinary Research, 1986;50(3) 297-306.

[61] Tinggi U. Essentiality and toxicity of selenium and its status in Australia: a review. Toxicology Letters, 2003;137(1-2) 103-110.

[62] Broadley MR, White PJ, Hammond JP, Zelko I, Lux A. Zinc in plants. New Phytologist, 2007;173(4) 677-702.

[63] Allen JG, Masters HG, Peet RL, Mullins KR, Lewis RD, Skirrow SZ, Fry J. Zinc toxicity in ruminants. Journal of Comparative Pathology, 1983;93(3) 363-377. 
[64] Fosmire GJ. Zinc toxicity. The American Journal of Clinical Nutrition. 1990;51(2) 225-227.

[65] Fränzle S, Markert B. The Biological System of the Elements (BSE) - a brief introduction into historical and applied aspects with special reference on "ecotoxicological identity cards" for different element species. (e.g. AS and Sn). Environmental Pollution, 2002;120(1) 27-45.

[66] EPA - Environmental Protection Agency. Standards for the use or disposal of sewage sludge. Washington, DC: USEPA; 1993. (40 CFR Part 257)

[67] CONAMA. Brazilian National Environment Council. Resolução CONAMA n ${ }^{\circ}$ 375/2006. Available: <http://www.mma.gov.br/port/conama/legiabre.cfm?codlegi=506>. Accessed: 09/08/2013.

[68] Oliveira FC, Mattiazzo ME. Metais pesados em Latossolo tratado com lodo de esgoto e em plantas de cana-de-açúcar. Scientia Agricola, 2001;58(3) 581-593.

[69] Oliveira KW, Melo WJ, Pereira GT, Melo VP, Melo GMP. Heavy metals in Oxisols amended with biosolids and cropped with maize in a long-term experiment. Scientia Agricola, 2005;62(4) 381-388.

[70] Rangel OJP, Silva CA, Bettiol W, Dynia JF. Efeito de aplicações de lodos de esgoto sobre os teores de metais pesados em folhas e grãos de milho. Revista Brasileira de Ciência do Solo, 2008;30(3) 583-594.

[71] Nogueira TAR, Oliveira LRO, Melo WJ, Fonseca IM, Melo GMP, Melo VP, Marques MO. Cádmio, cromo, chumbo e zinco plantas de milho e em Latossolo após nove aplicações anuais de lodo de esgoto. Revista Brasileira de Ciência do Solo, 2008;32(5) 2195-2207.

[72] Pires AMM, Mattiazzo ME. Cinética de solubilização de metais pesados por ácidos orgânicos em solos tratados com lodo de esgoto. Revista Brasileira de Ciência do Solo, 2007;31(1) 143-151.

[73] Merlino LCS, Melo WJ, Macedo FG, Guedes ACTP, Melo VP, Melo GMP. Bário, cádmio, cromo e chumbo em plantas de milho e em Latossolo após onze aplicações anuais de lodo de esgoto. Revista Brasileira de Ciência do Solo, 2010;34(6) 2031-2039.

[74] Borges MR, Coutinho ELM. Metais pesados do solo após aplicação de biossólido. I Fracionamento. Revista Brasileira de Ciência do Solo, 2004;28(3) 543-555.

[75] Camilotti F, Andrioli I, Marques MO, Silva AR, Tasso Júnior LC. Avaliação dos teores de metais pesados no solo e na planta de cana-de-açúcar sob adubação com lodo de esgoto e vinhaça. Bioscience Journal, 2009;25(6) 23-31.

[76] Camilotti F, Silva ARB, Marques MO. Biomass and yield of peanut grown on tropical soil amended with sewage sludge contaminated with lead. Applied and Environmental Soil Science, 2012;2012 1-6. doi:10.1155/2012/896090 
[77] Galdos MV, De Maria IC, Camargo OA. Atributos químicos e produção de milho em um Latossolo Vermelho eutroférrico tratado com lodo de esgoto. Revista Brasileira de Ciência do Solo, 2004;28(3) 569-577.

[78] Nogueira TAR, Franco A, He Z, Braga VS, Firme LP, Abreu-Junior CH. Short-term usage of sewage sludge as organic fertilizer to sugarcane in a tropical soil bears little threat of heavy metal contamination. Journal of Environmental Management, 2013;114 168-177.

[79] Simonete MA, Kiehl JC. Extração e fitodisponibilidade de metais em resposta à adição de lodo de esgoto no solo. Scientia Agricola, 2002;59(3) 555-563.

[80] Oliveira C, Sobrinho NMBA, Marques VS, Mazur N. Efeito da aplicação do lodo de esgoto enriquecido com cádmio e zinco na cultura do arroz. Revista Brasileira de Ciência do Solo, 2003;29(1) 109-116.

[81] Martins ALC, Bataglia OC, Camargo OA. Copper, nickel and zinc phytoavailability in an Oxisol amended with sewage sludge and liming. Scientia Agricola, 2003;60(4) 747-754.

[82] CETESB. Environmental Agency of the State of São Paulo. Aplicação de lodos de sistemas de tratamento biológico em áreas agrícolas - critérios para projeto e operação. São Paulo: CETESB; 1999. (Norma técnica, P4.230) Available: http:// www.cetesb.sp.gov.br/servicos/normas---cetesb/43-normas-tecnicas---cetesb>. Accessed: 09/08/2013.

[83] USEPA. United States Environmental Protection Agency. Method 3050B. Acid digestion of sediments, sludges, and soils. USEPA; 1996. Available: <http:// www.epa.gov/osw/hazard/testmethods/sw846/pdfs/3052.pdf>. Accessed: 09/22/2013.

[84] USEPA. United States Environmental Protection Agency. Method 3051A. Microwave assisted acid digestion of sediments, sludges, soils, and oils. USEPA; 2007. Available: <http://www.epa.gov/osw/hazard/testmethods/sw846/pdfs/3051a.pdf>. Accessed: 09/22/2013.

[85] Abreu MF, Berton RS, Andrade JC. Comparison of methods to evaluate heavy metals in organic wastes. Communications in Soil Science and Plant Analysis, 1996;27(5-8) $1125-1135$.

[86] Jackson ML. Soil chemical analysis. Englewood Cliffs: Prentice Hall; 1958.

[87] Alloway BJ, Jackson AP. The behavior of heavy metals in sewage sludge-amended soils. The Science of the Total Environment, 1991;100 151-176.

[88] Silva CA, Rangel, OJP, Dynia JF, Bettiol W, Manzatto, CV. Disponibilidade de metais pesados para milho cultivado em Latossolo sucessivamente tratado com lodos de esgoto. Revista Brasileira de Ciência do Solo, 2006;30(2) 353-364. 
[89] Oliveira FC, Mattiazzo ME. Mobilidade de metais pesados em um Latossolo Amarelo distrófico tratado com lodo de esgoto e cultivado com cana-de-açúcar. Scientia Agricola, 2001;58(4) 807-812.

[90] CETESB. Environmental Agency of the State of São Paulo. Valores orientadores para solos e águas subterrâneas no Estado de São Paulo. CETESB; 2005. Available: <http:// www.cetesb.sp.gov.br/solo/publicações-e-Relatórios/1-Publicações-/-Relatórios>. Accessed: 09/11/2013.

[91] CONAMA. Brazilian National Environment Council. Resolução CONAMA n ${ }^{\circ}$ 420/2009. Available: <http://www.mma.gov.br/port/conama/legiabre.cfm?codlegi=620>. Accessed: 09/08/2013.

[92] Macedo FG, Melo WJ, Merlino LCS, Ribeiro MH, Melo GMP, Camacho MA. Acúmulo e disponibilidade de cromo, cádmio e chumbo em solos tratados com lodo de esgoto por onze anos consecutivos. Semina: Ciências Agrárias, 2012;33(1) 101-114.

[93] Abreu CA, Raij B van, Abreu MF, González AP. Routine soil testing to monitor heavy metals and boron. Scientia Agricola, 2005;62(6) 564-571.

[94] Nogueira TAR, Melo WJ, Fonseca IM, Marcussi AS, Melo GMP, Marques MO. Fractionation of $\mathrm{Zn}, \mathrm{Cd}$ and $\mathrm{Pb}$ in a tropical soil after nine-year sewage sludge applications. Pedosphere, 2010;20(5) 545-556.

[95] Melo WJ, Aguiar OS, Melo GMP, Melo VP. Nickel in a tropical soil treated with sewage sludge and cropped with maize in a long-term field study. Soil Biology \& Biochemistry, 2007;39(6) 1341-1347.

[96] Nolan AN, Lombi E, McLaughlin MJ. Metal bioaccumulation and toxicity in soils Why bother with speciation? Australian Journal of Chemistry, 2003;56(3) 77-91.

[97] Hernandez-Soriano MC, Peña A, Mingorance MD. Soluble metal pool as affected by soil addition with organic inputs. Environmental Toxicology and Chemistry, 2013;32(5) 1027-1032.

[98] Silva LFM. Especiação iônica da solução do solo após sucessivas aplicações de solo de esgoto. Dissertação de Mestrado. Instituto Agronômico de Campinas; 2012.

[99] Barbosa Filho MP, Cantarella H, Wiethölter. Arroz, milho e trigo. In: Ferreira ME, Cruz MCP, Raij B van, Abreu CA. (ed.) Micronutrientes e elementos tóxicos na agricultura. Jaboticabal: CNPq/FAPESP/POTAFOS; 2001. p.285-318.

[100] ANVISA. Brazilian Health Surveillance Agency. Decreto $n^{\circ}$ 55.871/1965. Available: $<$ http://portal.anvisa.gov.br/wps/content/Anvisa+Portal/Anvisa/Inicio/Alimentos/ Assuntos+de+Interesse/Legislacao/Aditivos+Alimentares+e+Coadjuvantes+de+Tecnologia>. Accessed: 23/09/2013.

[101] ABIA. Brazilian Food Industry Association. Compêndio da legislação de alimentos. São Paulo: ABIA; 1985. 
[102] Kabata-Pendias A, Pendias H. Trace elements in soils and plants. 3rd ed. Boca Raton: CRC Press; 2001.

[103] Camilotti F, Marques MO, Andrioli I, Silva AR, Tasso Júnior LC, Nobile FO. Acúmulo de metais pesados em cana-de-açúcar mediante a aplicação de lodo de esgoto e vinhaça. Engenharia Agrícola, 2007;27(1) 284-293. 